Golden Gate University School of Law GGU Law Digital Commons

2000

Is There A Doctor in the House? Using Failure-toWarn Liability to Enhance the Safety of Online Prescribing

Chester S. Chuang

Golden Gate University School of Law, cchuang@ggu.edu

Follow this and additional works at: http://digitalcommons.law.ggu.edu/pubs

Part of the Health Law and Policy Commons

Recommended Citation

75 N.Y.U. Law Rev. 1452 (2000)

This Article is brought to you for free and open access by the Faculty Scholarship at GGU Law Digital Commons. It has been accepted for inclusion in Publications by an authorized administrator of GGU Law Digital Commons. For more information, please contact jischer@ggu.edu. 


\title{
IS THERE A DOCTOR IN THE HOUSE? USING FAILURE-TO-WARN LIABILITY TO ENHANCE THE SAFETY OF ONLINE PRESCRIBING
}

\author{
Chester Chuang*
}

\begin{abstract}
The ability to obtain prescription medications over the Internet without a proper prescription has inflamed regulators nationwide. Federal and state officials alike have proposed a host of new laws and regulations that attempt to limit this burgeoning phenomenon. Yet premature regulation of Internet prescribing could prevent consumers from realizing the tremendous benefits the Internet might one day provide to the American health care delivery system. In this Note, Chester Chuang argues that subjecting Internet prescribing to a traditional failure-to-warn liability framework, rather than to additional regulations, adequately will ensure patient safety while allowing for the necessary innovations that will legitimize the distribution of prescription medications over the Internet. He suggests that pharmaceutical manufacturers can satisfy their duty to warn by contractually obligating websites that dispense prescription medications to implement comprehensive patient information systems. Chuang concludes that the proper application of this framework to these patient information systems will make certain that pharmaceutical manufacturers strike the proper balance between patients' health and safety concerns and the possibilities of Internet prescribing.
\end{abstract}

\section{INTRODUCTION}

The learned intermediary doctrine exempts pharmaceutical companies from the general rule requiring manufacturers to warn consumers of dangers inherent in their products. ${ }^{1}$ Under this doctrine, to fulfill its legal duty to warn, a prescription drug manufacturer need only provide adequate warnings about its medications to the prescribing physician, and not to the ultimate user. ${ }^{2}$ At its core, the doctrine is

* Special thanks to Robert L. Rabin for his help in shaping this piece. This Note could not have been published without the extraordinary talents of Radha A. Pathak, Dahlia S. Fetouh, Michael J. Kasdan, Janet R. Carter, Rafael I. Pardo, and the staff of the New York University Law Review. Thanks also to Kenneth Hale and Lydia L. Chuang for their research assistance.

1 See, e.g., Reyes v. Wyeth Lab., 498 F.2d 1264, $1274-75$ (5th Cir. 1974) (stating that makers of unavoidably unsafe products have duty to provide proper warnings); Restatement (Third) of Torts: Products Liability $\$ 2$ (c) (1997) (same). The learned intermediary doctrine will be discussed further, see infra Part II.A.

2 See, e.g., Burton v. American Home Prods. Corp. (In re Norplant Contraceptive Prods. Liab. Litig.), 955 F. Supp. 700, 703 (E.D. Tex. 1997) ("Under the learned intermediary doctrine, 'when a drug manufacturer properly warns a prescribing physician of the dangerous propensities of its product, the manufacturer is excused from warning each patient who receives the drug. The doctor stands as a learned intermediary between the 
based on traditional notions of the ideal physician-patient relationship-the physician as a trusted father figure, and the deferential patient, confident in his care. The explosion of Internet prescribing, however, has forced a reevaluation of whether this traditional relationship is the only viable way to prescribe and dispense prescription medications. Prescription drugs are freely available on the World Wide Web, with or without a prescription, from sites with varying degrees of restrictions and reputability. ${ }^{3}$ In an online world where the physician is conspicuously absent, or at best virtual, the learned intermediary doctrine breaks down, leaving pharmaceutical manufacturers with the duty to warn the ultimate purchasers of the risks their medications carry. ${ }^{4}$ Because of the very nature of prescription drugs and the way they are distributed, however, most drug manufacturers are currently unable to provide adequate risk information directly to each patient. 5 Therefore, this duty effectively could preclude manufacturers from selling their products online. ${ }^{6}$

This Note argues that manufacturers can satisfy the duty to warn that is owed to consumers who purchase prescription medications from Internet prescribing sites by contractually obligating the websites to implement comprehensive patient information systems. Analyzing these systems under a traditional failure-to-warn liability framework will allow reputable sites to mature into reliable sources of prescription medications for consumers, while cutting off the supply of drugs to fraudulent sites without resorting to increased government regulation. Ideally, this framework will force manufacturers to weigh patients' health and safety with the commercial and practical advantages of Internet prescribing.

Part I of this Note chronicles the rise of Internet prescribing and the increased access to prescription medications it offers the everyday consumer. Part II outlines the learned intermediary doctrine and discusses why it is inapplicable to current online prescribing practices. This Part also describes the unique difficulties pharmaceutical manufacturers face when trying to implement a direct warning system, but

manufacturer and the ultimate consumer."” (quoting Alm v. Aluminum Co. of Am., 717 S.W.2d 588, 591-92 (Tex. 1986))), affd, 165 F.3d 374 (5th Cir. 1999); Krasuopolsky v. Warner-Lambert Co., 799 F. Supp. 1342, 1346 (E.D.N.Y. 1992) (noting that manufacturer's duty is to warn doctor, not patient); Windham v. Wyeth Lab., Inc., 786 F. Supp. 607, 611 (S.D. Miss. 1992) (same).

3 See infra notes 11-20 and accompanying text for a description of these siebsites.

4 The learned intermediary rule does not apply when a prescribing physician is absent, leaving manufacturers with the legal duty to warn patients directly about their medieations. See infra Part II.C.

5 For further discussion, see infra Parts II.A, M.C.

6 See infra note 94 and accompanying text. 
concludes by arguing that these difficulties should not dissuade manufacturers from exploring online prescribing. Part III presents a solution for conveying adequate patient warnings directly to the patient, taking into account the unique challenges that Internet prescribing presents. This Part proposes that the application of a traditional failure-to-warn analysis will enable manufacturers to use the Internet to create comprehensive patient information systems that satisfy manufacturers' duty to warn in an online prescribing situation. There are two ways this might be accomplished: first, by enhancing the online physician-patient relationship so that it falls within the confines of the learned intermediary doctrine, or second, by implementing Individualized Patient Reports (IPRs) without increasing the physician's role in the transaction, thus spurning the protection of the learned intermediary doctrine completely. Finally, this Part proposes that manufacturers, and not the government, must require websites to implement either of these systems in order to ensure the success of these patient safety measures.

\section{I}

\section{The Rise of Internet Prescribing}

Within the last few years, a multitude of pharmaceutical sites have emerged on the Internet, selling everything from prescription and over-the-counter medications to health and beauty aids. ${ }^{7}$ The exploding popularity of these sites is closely linked to the development of three new, increasingly popular, "lifestyle" medications designed to enhance quality of life rather than to cure disease: Viagra, for impotence; Propecia, for hair loss; and Xenical, for weight loss. ${ }^{8}$ Often, patients who wish to take these medications are embarrassed to ask their doctors for a prescription and find comfort in the privacy and the anonymity afforded them by ordering online.9 The allure of these sites is so strong that some experts predict that in the next five years

7 See Robin Herman, Drugstore on the Net (It's Quick, It's Convenient and It's Unregulated. Consumers Run the Risk of Harm With Do-It-Yourself Prescriptions), Wash. Post, May 4, 1999, at Z14 ("In the past year, hundreds of pharmaceutical sites have popped up on the Internet ....").

8 See Naftali Bendavid, Prescriptions via Internet Pose Dangers: Doctors Fear Patients Will Skip Supervision, Checkups, Chi. Ttib., June 16, 1999, \& 1, at 1; Sheryl Gay Stolberg, On-Line Prescription Practices Create Headache for Regulators, Chi. Thib., June $27,1999, \S 1$, at 8 (noting that online prescribing is tied to emergence of Viagra, Propecia, and Xenical).

9 See, e.g. Bendavid, supra note $8, \S 1$, at 1 (noting that Internet is attractive to "those who may be embarrassed to admit, even to their doctor, that they are impotent or concerned about their baldness or weight"). 
online sales for prescription drugs and health and beauty products may exceed $\$ 6$ billion. ${ }^{10}$

These websites fall roughly into two categories: "pharmacybased" and "prescribing-based."11 "Pharmacy-based" sites operate much like traditional corner drugstores. They are state-licensed and require an off-site doctor's prescription before they will dispense medications. ${ }^{12}$ These sites are regulated under conventional food and drug laws, ${ }^{13}$ and will thus not be the focus of this Note. "Prescribingbased" sites, on the other hand, circumvent the traditional models of prescription drug distribution. These types of sites further can be categorized as either Online Consultation or International Freelance sites. Online Consultation sites require customers to complete a brief medical questionnaire online, usually involving general physical information and details of concomitant medication use, which is then reviewed by the site's physician, who issues the prescription for the requested drug. ${ }^{14}$ The medication is then shipped directly by the site to the consumer. ${ }^{15}$ Usually, little information is available about the physician's qualifications, with some sites disclosing only that their

10 See Sarah A. Webster, Internet Drug Sales Investigated: Critics Raise Warning About Health Risks of Online Prescriptions, Detroit Nerrs, June 7, 1999, at A1, available in 1999 WL 3927805.

11 See Shari Roan, Your Friendly Neighborhood E-Drugstore: The New Online Pharmacies Offer Prompt, Hassle-Free Service, but Health Experts Worry That the Sites Also Pose Serious Potential for Misuse, L.A. Times, Sept. 20, 1999, at S1 (differentiating between "pharmacy-based" and "prescribing-based" sites).

12 See id. (describing how pharmacy-based sites operate). For examples of pharmacybased sites, see CVS Online Pharmacy Store (visited Sept. 17, 2000) <http://vrvv.cus.com;; Drugstore.com (visited Sept. 17, 2000) <http://wnv.drugstore.com>; PlanetRx Online Pharmacy \& Drugstore (visited Sept. 17, 2000) <http:/hnnv.planctricom>.

13 See Roan, supra note 11, at S1 (writing that pharmacy-based sites are "legitimate [and] state-licensed"). Pharmacy-based sites require patients to send prescriptions to the website or will contact directly patients' doctors for prescriptions before dispensing medication, much like mail-order pharmacies. They are regulated under the existing laws and regulations for mail-order pharmacies. See generally Gregory S. Munro, Regulation of Mail-Order Pharmacy, 12 J. Legal Med. 1 (1991) (describing laws and regulations governing mail-order pharmacies).

14 See Bernard S. Bloom \& Ronald C. Iannzcone, Internet Availability of Prescription Pharmaceuticals to the Public, 131 Anuals Internal Med. 830, 831-32 (1999) (detniling ordering process); Bendavid, supra note 8, \&1, at 1 (same); Herman, supra note 7, at Z14 (same). For examples of Online Consultation sites, see 24 Hour Viagrn and Propecia Clinic (visited Sept. 17, 2000) <http://www.24houronlinedrugs.com>; Doctors 2000 (visited Sept. 17, 2000) <http://www.worldrx.com>; KwikMed (visited Sept. 17, 2000) <http:/l www.kwikmed.com>; Lifestyle USA (visited Sept. 17, 2000) <http://inww.lirestyleusa.com>; Procare Clinic for Men (visited Sept. 17, 2000) <http://wnv.proearecliniccoms; ViagraOrders (visited Sept. 17, 2000) <http://wwww.futuredrugservices.com>.

15 See Lauran Neergaard, Playing Doctor: Online Pharmacies Allow PC Users to Skip the Physical, Newsday, Jan 6, 1999, at C3 (discussing types of drugs shipped from prescribing-based sites). 
physicians are licensed in foreign countries. ${ }^{16}$ International Freelance sites are based outside the United States. They do not require a prescription to order medication and do not offer physician consultation. ${ }^{17}$ Both types of prescribing-based sites generally include a waiver where the consumer releases the site from tort liability by clicking the "I AGREE" button. ${ }^{18}$

Prescribing-based sites afford the consumer around-the-clock availability and privacy as well as the promise of lower costs due to their reduced operating overhead. ${ }^{19}$ By eliminating face-to-face visits

16 See Bloom \& Iannacone, supra note 14, at 831-32 (describing lack of information available from prescribing-based sites regarding prescribing physicians). For examples of sites where the physicians reviewing the online questionnaire are licensed in foreign countries, see M.E.D. Clinic (visited Sept. 17, 2000) <http://www.ukyes.com> (U.K.); Norfolk Men's Clinic (visited July 5, 2000) <http://www.viagra.au.com> (Rom.); Pharmcom (visited Sept. 17, 2000) <http://www.pharmcom.com> (N.Z.).

17 See Bloom \& Iannacone, supra note 14, at 831-32 (discussing International Freelance sites). For an example of a website that does not require an online consultation, see $4 \mathrm{nRx}$ (visited Sept. 12, 2000) <http://www.4nrx.com>; see also DrugQuest (visited Sept. 12, 2000) <http://www.drugquest.com> (Internet portal that enables users to purchase prescription medications from foreign pharmacies without prescription).

18 See Bloom \& Iannacone, supra note 14, at 831. For examples of these waivers, see 2 Buy Viagra (visited June 7, 2000) <http://www.nethealthprescriptions.com/order.html>; 24 Hour Viagra and Propecia Clinic (visited July 5, 2000) <http:// www.24houronlinedrugs.com/viagra_waiver.htmb; Online Physicians (visited July 5, 2000) $<h t t p: / / w w w . o n l i n e p h y s i c i a n s . n e t / v i a g r a / c o n s u l t 1 . h t m>$. These types of waivers are termed click-wrap agreements. For a thorough explanation of click-wrap agreements, see Jerry $\mathrm{C}$. Liu et al., Electronic Commerce: Using Clickwrap Agreements, Computer Law., Dec. 1998, at 10. This Note will not focus on the enforceability of these click-wrap waivers, though courts historically have viewed negligence disclaimers with much skepticism. See Peter HI. Schuck, Rethinking Informed Consent, 103 Yale LJ. 899, 911 (1994) (noting that courts have tendency to override explicit waivers, especially in health care settings); Nicolas P. Terry, Cyber-Malpractice: Legal Exposure for Cybermedicine, 25 Am. J.L. \& Med. $327,361-62$ \& 362 n.282 (1999) (discussing cases where disclaimers have been invalidated in health care provider situations).

This Note also will not focus on the direct liability of the prescribing-based sites themselves. Though injured plaintiffs likely will sue both the website and the manufacturer, it is assumed that most plaintiffs will focus primarily on the manufacturers' liability due to their greater financial resources. For a more thorough explanation of this so-culled "deep pockets" mentality, see Audrey Chin \& Mark A. Peterson, Deep Pockets, Empty Pockets! Who Wins in Cook County Jury Trials at vii (1985) (finding that corporate and health care provider defendants had to pay more than individual defendants paid for similar injuries); Peter W. Huber, Liability: The Legal Revolution and Its Consequences 12 (1988) ("If the new tort system cannot find a careless defendant after an accident, it will often settle for a merely wealthy one."). But see Neil Vidmar, Empirical Evidence on the Deep Pockets Hypothesis: Jury Awards for Pain and Suffering in Medical Malpractice Cases, 43 Duke L.J. 217, 262-63 (1993) (finding no support for deep pockets effect).

19 See Herman, supra note 7, at Z14 (observing that virtual pharmacies offer "consumers the option of making purchases at any time without having to leave home ... [and] ship products directly from central distributors to customers, avoiding the overhead costs of a real storefront"); Roan, supra note 11, at S1 (noting that "online pharmacies hope to lower overhead costs and pass on lower prices to consumers"). 
to physicians and pharmacists, however, such sites may expose consumers to possible adverse drug reactions and other health risks. 20

The recent explosion of prescribing-based sites has state and federal authorities grappling with difficult enforcement issues. At the federal level, the reaction has been one of bewilderment. Although it is usually a violation of the Food, Drug and Cosmetic Act for Americans to order medications from a foreign country, 21 the law is extremely difficult to enforce. ${ }^{22}$ In fact, Americans have been buying drugs illegally from overseas mail-order catalogs for years, albeit in much more limited numbers. ${ }^{23}$ Recently, Representative Ron Klink introduced a bill that would require all online pharmacies to post identifying information about their doctors, pharmacists, and office addresses.24 President Clinton also has proposed legislation requiring

20 See Bendavid, supra note $8, \S 1$, at 1 (noting that there is "no way of knowing if the patient is answering the questions truthfully, or if a physical examination would reveal a more serious condition"); Herman, supra note 7, at Z14 ("Crities worry that without a faceto-face meeting with a doctor, customers can easily lie about their age and health status in order to get the regulated products they want...."); Roan, supra note 11, at S1 (indieating that American Medical Association believes that "risks in using these preseribing sites are overwhelming"); Webster, supra note 10, at A1 (writing that federal and state officials are "worried about the health risks to people ordering drugs without a doctor's visit or a pharmacist's review of potential drug interactions"); see also Bloom \& lannacone, supra note 14, at 833 (arguing that giving incorrect or false information to obtain prescription from one of these sites was "indirectly facilitated by preselected click-off choices available to the purchaser").

21 See Federal Food, Drug and Cosmetic Act, 21 U.S.C. $\$ 381$ (1994) (mandating that if imported drug appears to be (1) manufactured under unsanitary conditions, (2) forbidden or restricted in sale in the exporting country, or (3) adulternted or misbranded, such drug "shall be refused admission").

22 See American Med. Ass'n, Internet Prescribing, Board of Trustees Report No. 35-A99 (1999) <http://www.ama-assn.org/meetings/publid/annual99/reports/onsitc/bot/rti/ bot35.rtf [hereinafter Report of the AMA] (noting that Food and Drug Administration (FDA) has authority to prevent illegal purchase of prescription drugs oversens, but its effectiveness has been "extremely limited"); Neergaard, supre note 15, at C3 (writing that FDA "tries to stop shipments at the border but is largely unsuccessful"); Robert Pear, Online Sales Spur Tllegal Importing of Medicine to U.S., N.Y. Times, Jan. 10, 2000, at AI (noting that intercepting imported prescription drugs is extremely difficult); New Diet Drug Sets Off Medical Frenzy on Internet, Chi. Trib. (evening ed.), May 24, 1999, at 7 [hereinafter New Diet Drug] (same).

Complicating the issue further, the FDA allows for the importation of certain quantities of medication for personal use, even those not approved in the U.S. Sce Food \& Drug Admin., FDA/ORA Regulatory Procedures Manual ch. 9 (rev. May 12, 1998), available at <http:/www.fda.gov/ora/compliance_ref/rpm_new2/ch9pers.htmls. This exception is subject to various limitations. See Benten v. Kessler, 799 F. Supp. 281, 28487 (E.D.N.Y. 1992) (explaining "personal use exception" and limitations thereof).

23 See Herman, supra note 7, at Z14 (quoting Bill Hubbard, acting deputy commissioner for policy at FDA, saying: "We've always had these catalogues where people could buy from overseas, but it was a very small market ....' ); New Diet Drug, supra note 22, at 7.

24 See Internet Pharmacy Consumer Protection Act, H.R. 2763, 106th Cong. (1999). 
online pharmacies to receive federal certification from the Federal Food and Drug Administration (FDA) in order to dispense medication over the Web.25 However, since policing Internet prescribing would involve the FDA, Federal Trade Commission (FTC), Customs Service, Postal Service, Drug Enforcement Administration, and the states, no single agency has clear authority to address the issue uniformly. ${ }^{26}$ In fact, members of the House Commerce Committee recently complained in a letter to the FDA that "the federal effort appears uncoordinated and disorganized ... [ [and] it remains unclear which federal agencies or departments are in charge, or what the responsibilities are for each agency."27 Perhaps as a result of these difficulties, the FDA has indicated that the private sector, as well as state

25 The Internet Prescription Drug Sale Act of 2000 was transmitted jointly to the House Committees on Commerce and the Judiciary from the Secretary of Health and Human Services on June 9, 2000. See 146 Cong. Rec. H4173 (daily ed. June 9, 2000); see also Amy Goldstein, FDA Bids to Control Online Drug Sales, Wash. Post, Dec. 28, 1999, at A1 (describing Clinton's proposal); Robert Pear, Controls Sought for Drug Sales on the Internet, N.Y. Times, Dec. 28, 1999, at A1 (same); cf. Naftali Bendavid, Plan to Regulate Over-the-Web Drug Sales Draws Fire, Chi. Trib., Dec. 29, 1999, \&1, at 1 (arguing that expanding regulation in this area may not be well received).

26 Guidelines for prescription drugs are set out under the Federal Food, Drug and Cosmetic Act, 21 U.S.C. $\$ \$ 301-360$ ee (1994). The FDA has primary jurisdiction over drug labeling (prescription and over-the-counter) and over the advertising and promotion of prescription drugs. See 21 U.S.C. \$\$ 351-352, 393 (1994 \& Supp. IV 1998). The FTC has primary jurisdiction over over-the-counter drug advertising and can block dissemination of false or misleading advertising. See 15 U.S.C. $\$ \S 41,52-53$ (1994). Neither agency has indicated whether Internet marketing of drugs constitutes advertising, labeling, or both. See Kristen Green, Note, Marketing Health Care Products on the Internet: A Proposal for Updated Federal Regulations, 24 Am. J.L. \& Med. 365, 367 (1998). Doctors, pharmacists, and pharmacies are licensed by state boards of medicine and of pharmacy and must follow guidelines set out thereby. See, e.g., Fla. Stat. Ann. \$ 465.001-.187 (West 1998) (pharmacy); Fla. Stat. Ann. \$ 458.301-.349 (1998) (physicians); Ind. Code Ann. \& 25-26-13-1 to -29 (West 1999) (pharmacy); Ind. Code \$ 25-22.5-1-1.1 to -22.5-8 (1999) (physicians); Ohio Rev. Code Ann. $\$ 4729.01$-18 (West 2000) (pharmacy); Ohio Rev. Code Ann. $\$ 4731.01$ .143 (West 2000) (physicians); Va. Code Ann. \& 54.1-3300 to -3319 (Michie 2000) (pharmacy); Va. Code Ann. \$ 54.1-2900 to -2941 (Michie 2000) (physicians); Wis. Stat. \$ 450.01.18 (1998) (pharmacy); Wis. Stat. $\$ 448.01-40$ (1998) (physicians). Each state has established a Medical Practice Act that defines the process and procedures for granting a health professional license, renewing a license, and regulating medical practice within the state. See U.S. Dep't of Comm., Telemedicine Report to Congress (Jan. 31, 1997) [hereinafter Telemedicine], available at <http://www.ntia.doc.gov/reports/telemed/legal.htm>. Controlling illegal importation of drugs involves the Customs Service, the Postal Service, and the Drug Enforcement Administration. See Drugstores on the Net: The Benefits and Risks of On-Line Pharmacies: Hearings Before the Subcomm. on Oversight and Investigations of the House Comm. on Commerce, 106th Cong. 101 (1999) [hereinafter Drugstores on the Net] (statement of Janet Woodcock, M.D., Director, Center for Drug Evaluation and Research, FDA).

27 Robert Cohen, Regulation of Drugs Unraveling on the Web: Authorities Struggle to Rein in Business, Star-Ledger (Newark, N.J.), July 6, 1999, at 1. 
licensing and medical boards, would better be equipped to police prescribing-based sites than the federal government. ${ }^{28}$

Current state regulations, however, are premised on traditional conceptions of prescription drug distribution that fail to address the Internet prescribing problem. "Under existing law in the majority of states, prescribing prescription drugs to a patient outside the state where the physician is licensed is considered the unlicensed practice of medicine."29 In addition, most states' laws require licensed doctors to establish a physician-patient relationship before prescribing drugs to that patient. ${ }^{30}$ But since doctors, patients, and websites can all be

28 See Drugstores on the Net, supra note 26, at 95 (statement of Janet Woodcock) ("In the context of prescription drug sales over the Internet, government should encourage private sector leadership in achieving a safe marketplace."); Charles Marwick, Scveral Groups Attempting Regulation of Internet Rx, 281 JAMA 975, 975 (1999) (noting that "[t]he [FDA] views obtaining prescription drugs without the personal interaction of patient and physician as a significant problem but believes that it is one better handled by state licensing and medical boards than by the FDA").

In July 1999, the FDA adopted an Internet Sales Action Plan. See E-Drugs: Who Regulates Internet Pharmacies? Hearings Before the Senate Comm. on Heallh, Education, Labor and Pensions, 106th Cong. (2000) (statement of Jane E. Henney, MLD., Commissioner of Food and Drugs, FDA) [hereinafter Senate Testimony], available at <http:/ www.fda.gov/ola/2000/pharmsales.html>. The plan includes increased public and professional outreach, coordinating state and federal agencies as well as international agencies, monitoring websites involved in drug sales, and sending warning letters to websites. See id.

29 Report of the AMA, supra note 22, at 3; accord Telemedicine, supro note 26 ("In virtually all situations ... the state has required an out-of-state physician to obtain a full and unrestricted license before consulting directly with patients in the state."); Julie $M$. Kearney, Comment, Telemedicine: Ringing in a New Era of Health Care Delivery, 5 CommLaw Conspectus 289, 297 (1997) ("[M] ost states require a physician to obtain a full license in order to practice within that state."); Neergaard, supra note 15, at $\mathrm{C}$ ("It is illegal for doctors to prescribe for patients in a state where they're not licensed to practice."); see also Drugstores on the Net, supra note 26, at 256 (statement of Herman I. Abromovitz, M.D., American Medical Association) (expressing concern over dangerous Internet prescribing and encouraging state legislatures and licensing boards to work towards appropriate regulation); Alissa R. Spielberg, Online Without a Net: Physician-Patient Communication by Electronic Mail, 25 Am. J.L \& Med. 267, 291 (1999) (considering states' options for licensure of doctors engaged in telemedicine).

30 See, e.g., Cal. Bus. \& Prof. Code \$ 2242(a) (West 2000) ("Prescribing . . . without a good faith prior examination and medical indication therefor, constitutes unprofessional conduct"); Mo. Ann. Stat. $\$ 334.100(2)(4)($ h) (West 2000) (noting that bourd may file complaint against any physician who prescribes drugs "without sufficient examiantion"); see also Report of the AMA, supra note 22 ("[E]very state medical board agrees that prescribing drugs without physically examining a patient or reviewing his or her medical records is, in most cases, practicing medicine at a level far below the acceptable standard of medical care."); Herman, supra note 7, at Z14 ("States require licensed doctors to meet a 'standard of care' for a physician-patient relationship that includes personal interaction."); Neergaard, supra note 15, at $\mathbf{C}$ ("Licensed doctors . . . must meet standards of care that in most states require a patient relationship to prescribe drugs."). 
based in different states, state boards of pharmacy and medicine are unfortunately ill-equipped to police Internet prescribing. ${ }^{31}$

In a piecemeal attempt to regulate these sites, a few states have taken action. Illinois passed a law requiring any Internet site that ships to a patient in the state to have an Illinois pharmacy license; 32 Nevada's Board of Medical Examiners barred its doctors from making Internet sales unless they actually see the patient; ${ }^{33}$ medical boards in Wisconsin and Colorado have disciplined doctors who prescribed medications to patients they never examined; ${ }^{34}$ and other states currently are investigating these sites. ${ }^{35}$ Enforcement is confounded, however, by the fact that few of these sites reveal their geographic location, let alone specific identifying information about their physicians. ${ }^{36}$ In fact, very few doctors or pharmacists have been sanctioned for Internet prescribing. ${ }^{37}$

The private sector has also moved to address this thorny issue. The American Medical Association (AMA) has approved a resolution aimed at discouraging doctors from writing prescriptions through an Internet consultation. ${ }^{38}$ Pfizer Inc., the maker of Viagra, has filed a complaint with the FTC seeking to stop the prescribing of Viagra without adequate safeguards. Pfizer complains that the online questionnaires used by prescribing-based sites do not adequately convey the risks of concomitant use of nitrates, and fail to discover underlying medical problems that remain undiagnosed because of the lack of a

31 See Senate Testimony, supra note 28 ("[M]ost drug sales websites are actually mado up of multiple related sites and links, thereby making investigations much more complex and resource intensive."); Bendavid, supra note $8, \$ 1$, at 1 (noting that state medical and pharmacy boards are "poorly equipped to deal with cyberspace, where a patient in one state can order pills from a druggist in another state, with the prescription often written by a doctor in a third").

32 See 225 Ill. Comp. Stat. 85/16-a (West Supp. 2000).

33 See Herman, supra note 7, at Z14.

34 See id.

35 See Report of the AMA, supra note 22, at 5 (Arizona, Colorado, Connecticut, Illinois, Nevada, New Jersey, Ohio, Texas, Washington, and Wyoming); Herman, supra note 7, at Z14 (Wisconsin and Colorado); Neergaard, supra note 15, at C3 (Connecticut, Wyoming, New Jersey, and Kansas).

36 See Bloom \& Iannacone, supra note 14, at 831-32.

37 See Bendavid, supra note $8, \$ 1$, at 1 ("[As of June 16,1999,] fewer than ten doctors nationwide, and few if any pharmacists, have been disciplined for prescribing over the Internet.").

38 See American Medical Association Resolution 832, Guidelines for Medical Practice Through the Internet (visited July 8, 2000) <http://www.ama-assn.org/meetings/public/annual99/reports/onsite/rtf/h832.rtts (stating that "physician[s] should refrain from writing prescriptions for medication resulting only from a sale or consultation over the internet"); Cohen, supra note 27, at 1 (discussing shortcomings of formal regulation). 
physical exam. ${ }^{39}$ Pfizer has also contacted all state medical boards, asking them to remind doctors that it is improper to prescribe Viagra without examining the patient. 40 Drug manufacturers like Pfizer are right to be deeply concerned about the inadequate safeguards implemented by prescribing-based sites, since they will not be able to plead ignorance of these inadequacies if sued. By law, manufacturers are "presumed to possess an expert's knowledge of the arts, materials, and processes of the pharmaceutical business."41 This knowledge includes a familiarity with the distribution and administration of their products. ${ }^{42}$ Though obtaining prescription medication through foreign-based websites might be illegal, a line of cases holds that manufacturers must anticipate all reasonably foreseeable uses and misuses of their products. ${ }^{43}$ Accordingly, manufacturers can ill afford to wait

39 See Drugstores on the Net, supra note 26, at 253 (statement of Herman I. Abromowitz); Report of the AMA, supra note 22, at 3.

40 See Bendavid, supra note 8, \& 1, at 1; Roan, supra note 11, at \$1.

41 Reyes v. Wyeth Lab., 498 F.2d 1264, 1277 (5th Cir. 1974); cf. Navarro v. Fuji Heavy Indus., Ltd., 117 F.3d 1027, 1029 (7th Cir. 1997) (stating that:

The fact that as a Japanese firm it may not have known much about Chicago driving conditions is irrelevant .... Fuji intended to sell its cars in the Chicago area and is therefore charged with whatever knowledge can reasonably be imputed to automobile manufacturers, wherever located, desiring to serve that market.)

42 See, e.g., Mazur v. Merck \& Co., 964 F.2d 1348, 1363 (3d Cir. 1992) ("Prescription drug manufacturers are charged with knowledge of the distribution system in which their products are sold."); Reyes, 498 F.2d at 1277 (stating that drug manufacturers must be familiar "with practices and knowledge common in the drug industry as to distribution and administration of pharmaceutical products").

43 See, e.g., Gregory v. Cincinnati Inc, 538 N.W.2d 325, 329 (Mich. 1995) (stating that duty to warn includes foreseeable misuses); Darsan v. Guncalito Corp., 545 N.Y.S2d 594, 596 (App. Div. 1989) ("A manufacturer has a duty to warn of dangers associated with the reasonably foreseeable misuse of its product." (citations omitted)); Tanner v. Shoupe, 596 N.W.2d 805, 816-17 (Wis. Ct. App. 1999) (holding that whether battery was defective due to failure to wam against foreseeable misuse was issue for jury); see also Swayze v. McNeil Lab., Inc., 807 F.2d 464, 474 (5th Cir. 1987) (Goldberg, J., dissenting) ("[B]olh law and morality require McNeil [a pharmaceutical manufacturer] to monitor and ensure that the products it manufactures and markets are not generally used in an unreasonably dangerous fashion. If this entails some pressure to avoid deaths that McNeil can prevent, MeNeil is required to do no less."). But see Port Auth. v. Arcadian Corp, 189 F.3d 305, 320 (3d Cir. 1999) ("[P]laintiff can cite no authority (and we can find none) under either New Jersey or New York law which supports the existence of a duty to warn middlemen that consumers, after purchasing their products, may alter the products and harm third parties."); GainesTabb v. ICI Explosives, USA, Inc., 160 F.3d 613, 625 (10th Cir. 1998) ("[D]efendants had no duty to warn the suppliers of its product of possible criminal misuse.").

It is beyond the scope of this Note to determine whether a court indeed would decide whether ordering a prescription drug from an International Freelance site was reasonably foreseeable and thus apply failure-to-warn liability. In fact, a court in such a situation may hold the plaintiff contributorily negligent. Suffice it to say that it is uncharted territory and the very possibility of such lawsuits should spur manufacturers to take heed. 
for the government to take action to regulate these sites. ${ }^{44}$ Even if federal and state regulations were successful in inhibiting United States-based Online Consultation sites, foreign-based Online Consultation sites and International Freelance sites hardly would be affected. 45

Internet prescribing in its current state presents the courts with a scenario beyond the reach of the learned intermediary doctrine. With no discernible learned intermediary to rely upon, the courts will be forced to assign the duty to warn the patient to manufacturers, leaving them open to tremendous liability unless effective warnings are provided. 46

44 Government regulations may not be the most effective way to police this burgeoning phenomenon. Regulations will be unable to reach International Freelance websites. Sec Drugstores on the Net, supra note 26, at 99 (statement of Janet Woodcock) ("The most difficult problem to address is the online sale of drugs to U.S. residents by sellers in foreign countries."); Bendavid, supra note 25, at N1 ("There is at least one large group that for now will remain beyond the reach of regulators: foreign Web sites."); Pear, supra note 25, at $\mathrm{A1}$ (same).

Many fear that additional regulations will stifle Internet innovations. See John Henkel, Buying Drugs Online: It's Convenient and Private, but Beware of 'Rogue Sites,' FDA Consumer, Jan.-Feb. 2000, available in FDA Consumer <http://www.fda.gov/fdac/features/ 2000/100_online.html> ("Certain pharmacy industry representatives oppose legislation or additional powers for regulatory agencies on the premise that current laws are sufficient to address the problem."); Marilyn Werber Serafini, Drugs on the Web, 31 Nat'I J. 3281, 3311 12, 3314 (1999) (detailing tepid reaction to additional regulation of Internet prescribing by legislators and industry alike); see also Jeri Clausing, Internet Makes an Easy Target for Lobbyists and Lawmakers, N.Y. Times, Nov. 22, 1999, at C1 (arguing that "evolving technology could eliminate the need for rules over domain names disputes and problems like spam").

45 See Enforcing the Laws on Internet Pharmaceutical Sales: Where Are the Feds? Hearings Before Subcomm. on Oversight and Investigations of the House Comm. on Com. merce, 106th Cong. (2000) (statement of William K. Hubbard, Senior Associate Commissioner for Policy, Planning and Legislation, FDA) [hereinafter Hubbard Testimony], available at <http://www.fda.gov/ola/2000/internetsales.html> (stating that:

[The] FDA confronts the same obstacles facing other U.S. regulatory and law enforcement agencies seeking to hold foreign actors accountable for violations of Federal law. FDA efforts are mostly limited to requesting the foreign government to take action against the seller of the product, or asking the U.S. Customs Service ... to stop the imported drug at a U.S. port-of-entry.);

Herman, supra note 7, at Z14 ("The World Health Organization has considered the problems of Internet drug sales, but international action is nearly impossible because of different prescription standards in each country."); see also supra note 44 and accompanying text (describing difficulty in policing international websites).

This problem is not limited to prescription drugs. Various foreign gambling websites have been established to evade U.S. jurisdiction. See Mark G. Tratos, Gaming on the Internet, 3 Stan. J.L. Bus. \& Fin. 101, 107 (1997) ("[M]any virtual gaming operators who are beginning to offer services on the Internet are setting up their operations outside the United States ... to avoid criminal prosecution by being located physically outside of the jurisdiction of federal authorities.").

46 The liability assigned to prescription manufacturers in the absence of the learned intermediary rule will be discussed further, see infra Part II.C.1.b. 
III

Circumventing the Learned Intermediary: CONSEQUences of INTERNet PrescribING

\section{A. The Learned Intermediary Rule}

The learned intermediary rule limits a prescription drug manufacturer's duty to warn to "an obligation to advise the prescribing physician of any potential dangers that may result from the drug's use."47 By warning the doctor, the manufacturer relieves itself of any duty to warn the users of its products directly. ${ }^{48}$ As the Fifth Circuit explained:

Prescription drugs are likely to be complex medicines, esoteric in formula and varied in effect. As a medical expert, the prescribing physician can take into account the propensities of the drug, as vell as the susceptibilities of his patient. His is the task of weighing the benefits of any medication against its potential dangers. The choice he makes is an informed one, an individualized medical judgment bottomed on a knowledge of both patient and palliative.49

Proponents of the learned intermediary rule stress that it is based on "a desire not to intrude upon or disturb the well-established doctorpatient relationship." Tho Therefore, a physician, using her individualized medical judgment, should be entrusted with selecting the correct medication for each patient and specifically tailoring the warnings to him or her. Furthermore, courts have assumed that detailed side-effect information would in fact deter patients from taking the medication at all, despite their physician's best judgment.s1 Advocates of the

47 Reyes v. Wyeth Lab., 498 F.2d 1264, 1276 (5th Cir. 1974); see also Restatement (Third) of Torts: Products Liability § 6(d) (1997).

48 See, e.g., Stone v. Smith, Kline \& French Lab., 731 F.2d 1575, 1579-80 (11th Cir. 1984) (upholding learned intermediary rule); Mauldin v. Upjohn Co., 697 F.2d 644, 647 (5th Cir. 1983) (holding that manufacturer discharged duty to wam by adequately warning physician); Brochu v. Ortho Pharm. Corp., 642 F.2d 652, 661 (1st Cir. 1981) (stating that manufacturer must warn physician, not patient, of risks involved with prescription drugs); Sterling Drug, Inc. v. Cornish, 370 F.2d 82, 85 (8th Cir. 1966) (noting that "doctor is a learned intermediary between the purchaser and the manufacturer"). This is an exception to the general rule that manufacturers must warn all foreseeable ultimate users of their products of all dangers inherent within them. See Restatement (Third) of Torts: Products Liability \& 2(c) (1997).

49 Reyes, 498 F.2d at 1276.

50 Nancy K. Plant, The Learned Intermediary Doctrine: Some Nevy Medicine for an Old Ailment, 81 Iowa L. Rev. 1007, 1015 (1996); accord Swayze v. McNeil Lab., Inc, 807 F.2d 464, 471 (5th Cir. 1987) (noting that "warnings would only lead to confusion, and perhaps undermine the physician-patient relationship"); Dunkin v. Syntex Lab., Inc, 443 F. Supp. 121, 123 (W.D. Tenn. 1977) (stating that detailed warnings to patients might "interfere with the physician/patient relationship").

51 See, e.g, McKee v. American Home Prods. Corp., 782 P.2d 1045, 1055 (Whash. 1989) (writing that detailed information "may confuse and frighten the patient"); Lars Noah, 
rule also argue that it would be extremely difficult to fashion written warnings that are easily understood by lay people, yet sufficiently comprehensive to cover all of the possible side-effects, which are "inherently varied, complex, and dependent upon an individual patient's susceptibilities." 52 Even if devising an adequate warning were possible, pharmaceutical manufacturers must further ensure that it would reach patients who often neither receive the drug in its original packaging nor have any significant direct contact with the manufacturer. ${ }^{53}$

\section{B. The Learned Intermediary Rule Revisited}

The learned intermediary rule is premised on traditional conceptions of the ideal physician-patient relationship -a relationship that has been eroded heavily by the realities of our modern health care system. Today's managed care organizations often prevent patients from establishing long term relationships with physicians and usually provide patients with shorter consultations. ${ }^{54}$ Numerous FDA studies

Advertising Prescription Drugs to Consumers: Assessing the Regulatory and Liability Issues, 32 Ga. L. Rev. 141, 157 (1997) (noting that "warnings that contradict information supplied by the physician will undermine the patient's trust in the physician's judgment"); Plant, supra note 50, at 1015 (same); Teresa Moran Schwartz, Consumer-Directed Prescription Drug Advertising and the Learned Intermediary Rule, 46 Food Drug Cosm. L.J. 829, 830 (1991) (same); Catherine A. Paytash, Note, The Learned Intermediary Doctrine and Patient Package Inserts: A Balanced Approach to Preventing Drug-Related Injury, 51 Stan. L. Rev. 1343, 1347 (1999) (same).

52 Paytash, supra note 51, at 1347; see also Hill v. Searle Lab., 884 F.2d 1064, 1070 (8th Cir. 1989) (stating that "the information regarding risks is often too technical for a patient to make a reasonable choice"); Brooks v. Medtronic, Inc., 750 F.2d 1227, 1232 (4th Cir. 1984) (noting that direct warnings to patient would be "almost inevitably involved and longwinded"); Plant, supra note 50, at 1039-49 (describing rigorous requirements courts have imposed for adequate patient warnings); Charles J. Walsh et al., The Learned Intermediary Doctrine: The Correct Prescription for Drug Labeling, 48 Rutgers L. Rev. 821, 839 (1996) ("Given the educational and social differences among consumers, it is difficult if not impossible to draft patient labeling which will be beneficial to all users.").

53 See Plant, supra note 50, at 1015, 1049; Barbara Marticelli McGarey, Comment, Pharmaceutical Manufacturers and Consumer-Directed Information-Enhancing the Safety of Prescription Drug Use, 34 Cath. U. L. Rev. 117, 147 (1984). Manufacturers usually ship their products in bulk containers to the dispensing pharmacy. The pharmacy repackages the medication in the quantity prescribed by the physician and dispenses it to the patient. This will be discussed further, see infra Part II.C.1.a.

54 See Perez v. Wyeth Lab., Inc., 734 A.2d 1245, 1255 (N.J. 1999) (noting that since "managed care has reduced the time allotted per patient, physicians have considerably less time to inform patients of the risks and benefits of a drug"); Plant, supra note 50, at 102425 ("Patients enrolled in managed care organizations ... may be less likely to develop a long-term relationship with a single physician ... [and] are likely to spend less time with physicians."). As of 1995, 78\% of all privately insured Americans were members of man. aged care plans. See Rand E. Rosenblatt et al., Law and the American Health Care System 544 (1997). Likewise, over $80 \%$ of practicing physicians are employed by, or have entered into at least one contractual arrangement with, a managed care plan. See id. at 557. 
have shown that "most patients either do not receive information about prescription drugs from their doctors or, if they do .... they often do not understand it or forget it after leaving the office."ss Additionally, managed care organizations increasingly have usurped physicians' traditional discretion in prescribing decisions. ${ }^{56}$ As a result, the patient's best interests are often compromised in the face of many other competing interests. 57 Nonetheless, the learned intermediary rule remains widely accepted throughout the judiciary. 58 Because pre-

55 Schwartz, supra note 51, at 831 n.14. For a complete list of these studies, see 45 Fed. Reg. 60,754-56 (1980).

56 See Rosenblatt et al., supra note 54, at 568 ("[Managed care plans] use prospective utilization review techniques as well as practice guidelines to control physician utilization of resources. Managed care contracts with physicians typically include provisions vesting total discretion in the plan to make medical necessity determinations." ); Plant, supra note 50, at 1026-27 (noting that managed care plans have established formularies (i.e., lists of drugs that are covered by plan) of preferred drugs, required prior authorization before prescribing drugs not on formulary, required substitution of generic drugs, used monetary incentives for physicians to use cheaper drugs, and established protocols that require use of drugs in particular order). Managed care plans often threaten physicians with exclusion from their provider network (thus eliminating the physician's patient base) to compel compliance with these utilization standards. See Rosenblatt et al., supra note 54, at 559. Finally, some managed care plans reward doctors who provide or arrange for less care. See id. at 564.

Managed care plans have come under increasing attack for wrongrully superseding doctors' decision-making authority. See Herdrich v. Pegram, 154 F.3d 362, 376 (7th Cir. 1998) (noting that "[i]n order to minimize health care costs and fatten corporate prolits for HMOs, primary care physicians face severe restrictions on referrals and diagnostic tests, and at the same time, must contend with ever-shrinking incomes" $)$, rev'd, 120 S. C. 2143 (2000); Shea v. Esensten, 107 F.3d 625, 629 (8th Cir. 1997) (holding that plaintiff had right to know that HMO was "offering financial incentives that could have colored his doctor's medical judgement"); Plant, supra note 50, at 1023 ("Prescribing decisions are increasingly made or significantly affected by parties other than physicians, most notably third-party payors."); Amy Goldstein, How HMOs Became the Enemy, Wash. Post, Oct. 10, 1999, at A1 (detailing complaints levied against HMOs); David E. Rosenbaum, House Hears Grim Tales About Managed Care, N.Y. Times, Oct. 8, 1999, at A23 (same). But see Milt Freudenheim, Big H.M.O. to Give Decisions on Care Back to Doctors, N.Y. Times, Nov. 9, 1999, at A1 (noting that United Health Group is allowing doctors to malse treatment decisions without first consulting insurer). The House of Representatives recently passed a bill, H.R. 2723, 106th Cong. (1999), sharply limiting the ability of FMOs to enforce drug formularies and dictate treatment options. See 145 Cong. Rec. H9635-36 (doily ed. Oct. 7, 1999); see also Robert Pear, House Passes Bill to Expand Rights on Medical Care, N.Y. Times, Oct. 8, 1999, at A1 (describing bill).

57 See Plant, supra note 50, at 1031 ("M]t is erroneous to maintain that the physician is the sole decisionmaker regarding what drug is prescribed and that the doctor makes this decision based solely on what is best for the patient." ). But see Walsh et alh, supra note 52, at $877 \mathrm{n} 211$ (" $[$ T] $]$ here will be attempts to defeat the learned intermediary doctrine ... because the physician no longer has the freedom to prescribe what is best for the patient .... [N]otwithstanding the restrictions these plans place on physician autonomy, the doctor's independent medical judgement should be sufficient to defeat such claims.").

58 See Noah, supra note 51, at 161 ("[T]o date no jurisdietion has completely abandoned the learned intermediary rule ...."). There are limited exceptions to the learned intermediary rule. Some courts have held it inapplicable at mass immunization clinies. 
scription drugs serve an essential role in the health of our society and because in most cases existing physician-patient relationships can still provide more effective warnings than the manufacturer can give, 59 arguably, without the protection of the learned intermediary rule, manufacturers simply would cease to produce prescription medications because the duty to warn consumers directly would be too onerous a burden for them to sustain. ${ }^{60}$ In sum, the learned intermediary rule

See, e.g., Reyes v. Wyeth Lab., Inc., 498 F.2d 1264, 1277 (5th Cir. 1974) (stating that vaccine is "dispensed without the sort of individualized medical balancing of the risks to the vaccinee that is contemplated by the prescription drug exception"); Davis v. Wyeth Lab., Inc., 399 F.2d 121, 131 (9th Cir. 1968) (noting that "although the drug was denominated a prescription drug it was not dispensed as such"). These cases have been reversed to somo extent by the National Childhood Vaccine Injury Act of 1986, 42 U.S.C. $\$ \$ 300 a a-1$ to -34 (1994). The Act created a federal no-fault compensation scheme to compensate individuals injured as a result of any one of seven compulsory childhood vaccines. Alternatively, plaintiffs can choose to pursue a tort claim, but cannot base a claim on a failure to provide direct warnings to an injured party.

One court has refused to apply the learned intermediary rule to oral contraceptives. See MacDonald v. Ortho Pharm. Corp., 475 N.E.2d 65, 69 (Mass. 1985) (noting that patients are actively involved in birth control decisions, resulting in limited roles for doctor). For other examples of courts that have recognized the oral contraceptive exception, see Hill v. Searle Lab., 884 F.2d 1064 (8th Cir. 1989); Odgers v. Ortho Pharm. Corp., 609 F. Supp. 867 (E.D. Mich. 1985); Stephens v. G.D. Searle \& Co., 602 F. Supp. 379 (E.D. Mich. 1985). Odgers and Stephens were recently criticized as an incorrect statement of Michigan law in Reaves v. Ortho Pharm. Corp., 765 F. Supp. 1287, 1290 (E.D. Mich. 1991). Hill was repudiated by the Supreme Court of Arkansas in West v. Searle \& Co., 806 S.W.2d 608, 614 (Ark. 1991).

A recent salvo against the learned intermediary rule was fired by the New Jersey Supreme Court in Perez v. Wyeth Lab., Inc., 734 A.2d 1245 (N.J. 1999). The court declared that "[c]onsumer-directed advertising of pharmaceuticals ... belies each of the premises on which the learned intermediary doctrine rests" and concluded that pharmaceutical manufacturers who utilize direct-to-consumer advertisements also must provide adequate warnings to the consumer within those advertisements. Id. at 1256-57. Courts continue to disagree over whether the learned intermediary rule should be applicable in the face of direct-to-consumer advertising; indeed, the New Jersey Supreme Court acknowledged that its decision was in direct conflict with a contemporaneous one by the Fifth Circuit. See id. at 1256 ("We acknowledge that the Fifth Circuit recently held that under Texas law, the learned intermediary doctrine does apply in the context of Norplant."). Compare id., with Harrison v. American Home Prods. Corp. (In re Norplant Contraceptive Prods. Liab. Litig.), 165 F.3d 374, 379 (5th Cir. 1999) (holding that, although manufacturer was engaged in aggressive marketing, "as long as a physician-patient relationship exists, the learned intermediary doctrine applies").

59 This will be discussed further, see infra Part II.C.1.a.

60 See Harrison, 165 F.3d at 379 ("Our understanding of the rationale of the learned intermediary doctrine, at least in substantial part, is that it seeks to encourage the drug manufacturer to make available prescription drugs despite potentially harmful side effects."); Perez, 734 A.2d at 1259 ("[M]anufacturers are not made guarantors against remotely possible, but not scientifically-verifiable, side-effects of prescription drugs, a result that could have a 'significant anti-utilitarian effect.'"); Michael D. Green, Statutory Compliance and Tort Liability: Examining the Strongest Case, 30 U. Mich. J.L. Reform 461, 467 (1997) (writing that product liability claims can cause drug manufacturers to stop research and development, unnecessarily delay new drugs, or withdraw beneficial drugs); 
might be viewed as a rough judicial compromise between the commercial interests of the manufacturers, the practical advantages of the wide availability of prescription medications, and the health and safety of patients.

Courts facing Internet prescribing-related injury claims, however, will find it difficult to apply the learned intermediary rule.61 It is widely recognized that the learned intermediary rule should not apply when drugs are dispensed in the absence of a health care provider.62 Prescribing-based sites fall squarely within such a situation. In the best case scenario, a prescription drug is mailed directly to the patient's home on the basis of the patient's answers to a brief online questionnaire that supposedly was reviewed by an unseen physician. At worst, using an International Freelance site, the patient orders the medication without even going through the pretense of an online consultation and without ever obtaining a prescription. It is doubtful that even at an Online Consultation site, any health care professional balances the risks and the benefits of specific medications for individual patients as originally envisioned by the learned intermediary rule. As a result, manufacturers are left with the duty to provide risk information directly to any patient that obtains their medications in this fashion.

\section{Conveying Adequate Warnings Directly to the Patient}

The most common proposal to convey adequate warnings directly from manufacturer to patient is through the Patient Package Insert (PPI).63 PPIs are leaflets directly distributed with prescription drugs to the patient that describe in lay language the drug's indications, directions for use, and side effects. The FDA currently only requires

Walsh et al, supra note 52, at 823 (arguing that "imposing liability for insdequate patient warnings could adversely affect the availability and affordability of socially beneficial medicines").

61 See Terry, supra note 18, at 346 (noting that manufacturers who use web marketing circumvent learned intermediary).

62 See Restatement (Third) of Torts: Products Liability $\S 6(d)$ (1997). The drafting committee took pains to note that "direct warnings and instructions to patients are warranted for drugs that are dispensed or administered to patients vilhout the personal intervention or evaluation of a health-care provider." Id. at $\$ 6 \mathrm{cmt}$. e; see also Reyes, $493 \mathrm{~F} .2 \mathrm{~d}$ at 1276 ("[T] he manufacturer of a prescription drug who knows or has reason to know that it will not be dispensed as such a drug must provide the consumer with adequate information so that he can balance the risks and benefits of a given medieation himsclf.").

63 See Plant, supra note 50, at 1032-38 (describing development of pationt package inserts (PPIs)); Schwartz, supra note 51, at 847 (noting that courts should consider requiring PPIs for advertised drugs); McGarey, supra note 53, at 148-49 (indicating that manufacturers should be obligated statutorily to include PPIs with their drugs); Paytash, supra note 51, at 1368 (proposing FDA-mandated program of PPIs). 
that PPIs be distributed with a small group of medications, including oral contraceptives, ${ }^{64}$ estrogens, ${ }^{65}$ progestational drug products, ${ }^{66}$ and certain asthma inhalers, ${ }^{67}$ due to the high degree of patient involvement in the decision whether to use such medications, together with the potential for severe complications. ${ }^{68}$ In 1995, the FDA proposed a rule requiring drug manufacturers to include "useful" patient information with seventy-five percent of new prescriptions by 2000 and ninety-five percent by 2006.69 Since adequate patient information for pharmaceuticals is currently produced for a limited number of medications, and indeed, extensive patient information has even been incorporated into prescription drug advertisements, ${ }^{70} \mathrm{PPIs}$ seem at first glance to be an adequate solution to satisfying a manufacturer's duty to warn.

\section{An Incomplete Solution}

Advocates of mandatory PPIs, however, continue to envision them only as an adjunct form of patient information, secondary to the counseling provided by physicians. ${ }^{71}$ This reluctance to embrace PPIs as a primary source of drug information stems from two main concerns. First, as a result of the unique distribution system for prescription drugs, physicians are in a much better position to communicate directly with patients than are manufacturers. Second, the exacting judicial standard to which PPIs are subjected results in little actual protection from failure-to-warn liability.

\footnotetext{
64 See 21 C.F.R. $\$ 310.501$ (2000).

65 See 21 C.F.R. $\$ 310.515$ (2000).

66 See 21 C.F.R. $\$ 310.516(2000)$.

67 See 21 C.F.R. $\$ 201.305(2000)$.

68 See Plant, supra note 50, at 1032.

69 See 60 Fed. Reg. 44,182-44,252 (1995). The FDA previously had proposed expanding the PPI requirement to all prescription medications. See 44 Fed. Reg. 40,016 (codified at 21 C.F.R. $\$ 203$ (1981)) (1979). The regulation was quickly revoked a few years later, mostly due to a lack of support from the health care community. See Revocation of Patient Package Insert Requirements, 47 Fed. Reg. 39,147, 39,153 (1982); Plant, supra note 50, at 1033 (identifying development of voluntary, private-sector patient information programs as well as administrative pressures to "deregulate" as other reasons for revocation).

70 For an example, see Roche's full-page advertisement for Xenical, N.Y. Times, Oct. 1, 1999, at A17.

71 See Noah, supra note 51, at 177 ("IN]o one suggests that PPIs should fully replace professional labeling."); Schwartz, supra note 51, at 847 (suggesting that PPIs should be required in addition to adequate consumer warnings in manufacturers' advertisements); McGarey, supra note 53, at 148 ("Even with consumer-directed labeling, the primary responsibility for informing consumers about their prescriptions would remain with physicians."); Paytash, supra note 51, at 1369 ("[A] comprehensive FDA-mandated system of PPIs for all prescription drugs would most effectively complement the information about those drugs that patients receive from their doctors.").
} 
a. Prescription Drug Distribution. As a result of the distinctive distribution system for prescription medications, pharmaceutical manufacturers rarely have an opportunity to communicate directly with the end users of their products. Approximately eighty percent of all branded prescription products are sold through drug wholesalers.72 These wholesalers resell the medication to retail pharmacies and hospitals. ${ }^{73}$ The medication arrives in bulk at the pharmacies where pharmacists repackage it into smaller quantities, dispense it to the patient as directed by a physician's prescription, and provide counseling. ${ }^{74}$ Therefore, any mandatory PPI program still ultimately forces manufacturers to rely on physicians and pharmacists to distribute the varnings. ${ }^{75}$ Furthermore, because manufacturers have little information on the individual characteristics of a specific patient using their medication or on the disease state the patient is trying to treat with their medication, PPIs must list comprehensively all possible adverse effects for all possible patients and treatment scenarios. Since medications have multiple indications and side effects that can vary based on the dose that is prescribed or even with the patient's race or gender, and contraindications can differ depending on the patient's concomitant drug therapy and other disease states, physicians and pharmacists have important roles in individualizing drug warnings. ${ }^{76}$ Health care professionals perform the essential function of sifting through the myriad of possible warnings and highlighting the most important ones for each individual patient's situation. Without them, a PPI can easily "overwarn" a patient, leading to confusion or ungrounded fear in her prescribed therapy by flooding her with excessive amounts of informa-

72 See Sheryl L. Szeinbach, Drug Distribution, in Pharmacy and the U.S. Health Care System 317, 321 (Jack E. Fincham \& Albert I. Wertheimer eds., 2d ed. 1998) (“[A]bout 80 percent of branded pharmaceutical products were sold through drug wholesalers; 1.3 percent through practitioners; 15.7 percent direct to retailers, and the rest through other channels."); Maura J. Monaghan \& Michael S. Monaghan, Do Market Components Account for Higher US Prescription Prices?, 30 Annals Pharmacotherapy 1489, 1491 (1996) (providing figure detailing channels of drug distribution).

73 See Szeinbach, supra note 72, at 321 (listing major customers of wholesalers).

74 See Kathleen A. Johnson, Emerging Roles for Pharmacists, in Pharmacy and the U.S. Health Care System, supra note 72, at 217, 235 (noting that dispensing, labeling, and counseling are primary components of pharmacy practice). The role of pharmacists, however, is also expanding to encompass "pharmaceutical care." See id. at 226-34 (describing "pharmaceutical care" as emphasizing consultation over dispensing medientions).

75 See Plant, supra note 50, at 1075.

76 See Noah, supra note 51, at 175 (stating that physicians are best equipped to tailor discussion of drug therapy to needs of individual patients); Paytash, supra note 51, at 1366 (discussing ability of physician to tailor warning to patient's individual needs, circumstances, and cognitive abilities). 
tion. ${ }^{77}$ Thus, within the conventional drug distribution system, the health care professional, with or without a mandatory PPI program, remains optimally situated to provide the best quality information most efficiently to the patient.

b. An Exacting Legal Standard. In cases that find an exception to the learned intermediary rule, manufacturer-provided warnings are scrutinized under rigorous failure-to-warn standards. ${ }^{78}$ In applying this analysis, courts begin by assuming that all risks, no matter how remote, merit a warning directed to the consumer. ${ }^{79}$ For example, in Davis v. Wyeth Laboratories, Inc., ${ }^{80}$ the plaintiff had less than a one in a million chance of contracting polio from the manufacturer's vaccine. ${ }^{81}$ Nevertheless, the court held that failing to warn of this risk rendered the vaccine unreasonably dangerous. ${ }^{82}$ Likewise, the court in Reyes $v$. Wyeth Laboratories, ${ }^{83}$ while acknowledging that the risk of contracting polio from the manufacturer's vaccine was "foreseeable

77 See Dunn v. Lederle Lab., 328 N.W.2d 576, 580 (Mich. Ct. App. 1982) ("[E]xcessive warnings on product labels may be counterproductive."); Plant, supra note 50, at 1070.71 (noting that overwarning may dilute more important warning information); A.D. Twerski et al., The Use and Abuse of Warnings in Product Liability-Design Defect Comes of Age, 61 Cornell L. Rev. 495, 514-17 (1976) (noting that effective warnings must select carefully significant risks to warn about).

78 See Plant, supra note 50, at 1038-39 (describing failure-to-warn analysis used by courts); Schwartz, supra note 51, at 845-46 (arguing that failure-to-warn standard without learned intermediary rule is exacting and will be difficult to meet). But see Perez v. Wyeth Lab. Inc., 734 A.2d 1245, 1257 (N.J. 1999) (holding that under New Jersey law, duty to warn presumptively is met by compliance with federal labeling).

79 See, e.g., Givens v. Lederle, 556 F.2d 1341, 1345 (5th Cir. 1977) (holding that manufacturer must warn consumer of three million to one risk); Snawder v. Cohen, 749 F. Supp. 1473, 1475 (W.D. Ky. 1990) (stating that warnings required even if number of consumers who may be harmed is not large); McEwen v. Ortho Pharm. Corp., 528 P.2d 522, 530 (Or. 1974) (writing that defendant has duty to warn of statistically insignificant possibility of injury to plaintiff); Plant, supra note 50, at 1042 ("[C]ourts assume, without much analysis, either that all risks merit a warning to the consumer, or that a particular risk is significant enough to warrant a warning."); see also James A. Henderson, Jr. \& Aaron D. Twerski, Doctrinal Collapse in Products Liability: The Empty Shell of Failure to Wam, 65 N.Y.U. L. Rev. 265, 277 (1990) ("Many courts that acknowledge negligence as the substantive basis of failure-to-warn liability nevertheless insist on behaving as though strict liability were somehow being applied."); Michael S. Jacobs, Toward a Process-Based Approach to Failure-to-Warn Law, 71 N.C. L. Rev. 121, 141 (1992) ("[A] distinct minority of courts refuses to accept the basic principle that manufacturers need not warn about remote risks.").

80399 F.2d 121 (9th Cir. 1968).

81 See id. at 130.

82 See id. at 129-30 (acknowledging that risk was miniscule, yet qualitatively severe enough to require warning).

83498 F.2d 1264 (5th Cir. 1974). 
statistically, although unknowable individually," nonetheless held the manufacturer liable for not warning of the risk..$^{84}$

Second, courts demand that printed warnings, even those that encompass all possible risks, be worded in a particular way.85 In MacDonald v. Ortho Pharmaceutical Corp. ${ }^{86}$ Ortho's patient warnings stated that "[t]he most serious known side effect is abnormal blood clotting which can be fatal."87 Ortho's patient booklet elaborated on this statement, describing the clots as life threatening if they "break loose and then lodge in the lung or if they form in other vital organs, such as the brain." 88 Still, the court upheld the jury's determination that "the absence of a reference to 'stroke' in the warning unduly minimized the warning's impact or failed to make the nature of the risk reasonably comprehensible to the average consumer." 89

Third, courts often will ease the plaintiff's usual burden of proving causation in failure-to-warn cases. ${ }^{90}$ In typical failure-to-warn cases, once the plaintiff has established the manufacturer's duty to provide a warning, she then must prove that she "would have read, understood, and heeded an adequate warning, thus avoiding the injury in question." 1 In a prescription drug scenario, however, some courts establish a rebuttable presumption in favor of the plaintiff that if she had received the warning, she would not have used the product.92

84 Id. at 1294.

85 See Henderson \& Twerski, supra note 79, at 318-19 \& 319 n.220 (listing analogous cases); Jacobs, supra note 79, at 149 (noting that:

By scrutinizing closely the seemingly trivial details of type size, warning loestion, and relative degree of expressed urgency, and by permitting outcomes to hinge on the presence or absence of one or two seemingly innocuous words, courts impose upon manufacturers a duty of virtual perfection, easily breached, and satisfied only by chance.);

Plant, supra note 50, at 1043 (1996) ("[C]ases also impose a signifieant burden on the manufacturer to ensure that the waming is artfully worded.").

86475 N.E.2d 65 (Mass. 1985).

87 Id. at 67 n.3.

88 Id. at 67 n.4.

89 Id. at 71-72.

90 See Jacobs, supra note 79, at 162 ("For warnings claims, almost all courts bave adopted one of two approaches to causation, either of which malies it relatively easy for plaintiffs to satisfy their burden of proof."); Plant, supra note 50, at 1049 (vriting that when courts require drug manufacturers to warn patient directly, they bave been "deferential to plaintiffs in establishing the cause-in-fact element").

91 Jacobs, supra note 79, at 161.

92 See, e.g., Stanback v. Parke, Davis \& Co., 657 F.2d 642, 646 n.5 (4th Cir. 1981) (stating that although manufacturer did not have duty to warn ultimate consumer, plaintiff "would be entitled to the presumption that a warning, had it been given, would have bren heeded"); Reyes v. Wyeth Lab., 498 F.2d 1265, 1281 (5th Cir. 1974) ("Where a consumer, whose injury the manufacturer should have reasonably foreseen, is injured by a produet sold without a required waming, a rebuttable presumption will arise that the consumer would have read any warning provided by the manufacturer, and acted so as to minimize 
Even those courts that have not granted such a presumption have employed a subjective standard for establishing causation, allowing the plaintiff to testify as to whether she would have heeded an adequate warning. 93

Critics complain that applying such demanding standards to prescription drugs overdeters prescription drug manufacturers, thereby reducing the availability of medication. ${ }^{4}$ Indeed, under these stan-

the risks."); Seley v. G.D. Searle \& Co., 423 N.E.2d 831, 838 (Ohio 1981) ("[W] warning is given, or where an inadequate warning is given, a rebuttable presumption arises, beneficial to the plaintiff, that the failure to adequately warn was a proximate cause of the plaintiff's ingestion of the drug."); Jacobs, supra note 79, at 162 ("[A rebuttable presump. tion] frees plaintiffs from the obligation to prove either their general inclination to read and obey product warnings or the fact that they have actually done so in the particular case."); Plant, supra note 50, at 1050 ("In some cases when courts have held that the manufacturer had a duty to warn the patient directly, the patient is aided by a rebuttable presumption: if he would have received the warning, he would not have used the product."); Schwartz, supra note 51, at 847 ("Some courts, recognizing the difficulty of proving causation in warning cases, have created a rebuttable presumption of a causal linkage in such cases."); cf. also Henderson \& Twerski, supra note 79, at 278 ("Many courts have held that when the defendant fails to provide an adequate warning, it is presumed that such a warning would have been read and heeded by the user had it been given.").

93 See MacDonald, 475 N.E.2d at 72 (stating that:

The jury were free, however, to credit MacDonald's testimony that she would not have used the pills had she been advised of the danger of 'stroke,' and to infer that an explicit reference to the risk of stroke might tip the balance in a reasonable person's choice of a contraceptive method.);

Jacobs, supra note 79, at 162-63 (stating that courts that do not use rebuttable presumption "employ a subjective standard for establishing causation, allowing a plaintiff to testifyafter the fact of his injury, of course-as to whether he would have read and heeded an adequate warning had the defendant placed one on its product"); Plant, supra note 50, at 1053 (noting that courts grant plaintiffs "considerable leeway in showing that an adequate warning would have changed [their] decision[s]"); see also Henderson \& Twerski, supra note 79, at 305 ("A plaintiff typically can offer little more than self-serving testimony and anecdotal evidence to establish her proximate causation case.").

94 See Green, supra note 60, at 467 (identifying arguments that tort law results in overdeterrence that may cause beneficial drugs to be withdrawn from marketplace); $W$. Kip Viscusi et al., Deterring Inefficient Pharmaceutical Litigation: An Economic Rationale for the FDA Regulatory Compliance Defense, 24 Seton Hall L. Rev. 1437, 1470-71 (1994) (arguing that imposition of liability has induced manufacturers to leave vaccine market altogether); Walsh et al., supra note 52, at 874 (noting that if enough jurisdictions had accepted direct duty to warn standard for oral contraceptives, standard may have driven them off market or made them substantially less affordable). But see Teresa Moran Schwartz, Prescription Products and the Proposed Restatement (Third), 61 Tenn. L. Rev. 1357, 1401 (1994) (finding little evidence of liability system's adverse impact on pharmaceutical industry).

Various alternatives to traditional failure-to-warn analysis, such as a regulatory compliance defense, have been proposed. See Richard C. Ausness, The Case for a "Strong" Regulatory Compliance Defense, 55 Md. L. Rev. 1210, 1213 (1996) ("[A] strong regulatory compliance defense would ... more than offset any negative effects that the defense might have on product safety and victim compensation."); Green, supra note 60 , at 508 (writing that FDA regulatory compliance defense is not "unproblematic"); Henderson \& Twerski, supra note 79 , at 270 ("Concepts such as risk foreseeability, risk-utility balancing, and 
dards, manufacturers cannot realistically rely on the distribution of PPIs to fulfill their duty to warn in the context of Internet prescribing situations. When the consumer orders a medication from a prescribing-based site, it is dispensed with little physician interaction and shipped directly to the consumer. Because the PPI would become the patient's primary source of information without a health care professional readily available to interpret it, the usual worries that accompany PPIs are heightened. Thus, the PPI is a particularly unrealistic solution to bridge the warning gap so prevalent in online prescribing transactions. Moreover, the exacting liability standards used to analyze PPIs ${ }^{95}$ may deter manufacturers from relying on them at all, necessarily precluding them from selling medications online unless other realistic direct-warning systems can be designed. In sum, tremendous concerns abound regarding both patient safety and the ability of drug manufacturers to insulate themselves sufficiently from liability, threatening the continuing viability of Internet prescribing and distribution.

\section{The End of Internet Prescribing?}

A well-run prescribing based site-operating within the contours of healthy physician-patient relationships-could offer certain segments of the population distinct practical advantages over brick and mortar doctors' offices and pharmacies. These advantages include unparalleled access to health care providers both nationvide and worldwide, the convenience of around-the-clock availability, increased privacy, and lower costs.96 Additionally, the tremendous autonomy

proximate causation are so devoid of content in the failure-to-iwam context that they cannot hope to test the bona fides of the plaintiff's claim."); Peter Huber, Safety and the Second Best. The Hazards of Public Risk Management in the Courts, 85 Colum. L. Rev. 277,335 (1985) ("Requiring-or at least strongly encouraging-the courts to respect the comparative risk choices made by competent, expert agencies would inject a first, small measure of rationality into a judicial regulatory system that currently runs quite vild."); Jacobs, supra note 79, at 177 ("Because the content-based appronch to wamings law has failed, courts need to replace their minute inquiries into the details of risk and adequacy with a method of analysis that focuses on the procedures used by the manufacturer prior to the adoption and publication of its warning information."); Plant, supra note 50, at 1010 ("Principles should be adapted from the informed consent context to modify the obligations of pharmaceutical manufacturers so as to accommodate the unique nature of prescription drugs and medical devices." ); Teresa Moran Schwartz, The Role of Federal Safety Regulations in Products Liability Actions, 41 Vand. L. Rev. 1121, 1168 (1988) (arguing that "federal regulatory standards should not be treated as conclusively or presumptively adequate measures of safety under the common law"); Viscusi et al, supr, at 1439 (stating that "tort liability should be limited through federal legislation"). The appropriate state of failure-to-warn doctrine is beyond the scope of this Note; the risk of potential liability is the emphasis here, not how that liability will be, or should be, dctermined.

95 See supra notes $78-93$ and accompanying text.

96 See Hubbard Testimony, supra note 45 (detailing the "many" benetits of prescription drug sales over the Internet); Senate Testimony, supra note 28 (noting that benefits include 
the Internet provides patients can spur them to learn more about their medical conditions and history as well as to research their medications more thoroughly. 97 More generally, the lessons learned from developing effective prescribing-based sites can help harness the Internet as a tool to streamline the massive information exchanges between physi-

access to drugs for the disabled or otherwise home-bound, for whom a trip to the pharmacy can be difficult; the convenience of shopping 24 hours a day; an almost unlimited number of products for customers; and privacy for those who don't want to discuss their medical condition in a public place);

Drugstores on the Net, supra note 26, at 96 (statement of Janet Woodcock) ("Legitimate prescription drug sales on the Internet can provide tremendous benefits to consumers."); American Med. Ass'n, Guidelines for Medical Practice Through the Internet, Resolution 832 (1999) <http://www.ama-assn.org/meetings/public/annual99/reports/onsite/rtf/h832.rtf> (stating that Internet medicine may be used "to reduce cost and improve access to health care delivery by preventing unnecessary patient travel"); Barbara J. Tyler, Cyberdoctors: The Virtual Housecall-The Actual Practice of Medicine on the Internet Is Here; is it a Telemedical Accident Waiting to Happen?, 31 Ind. L. Rev. 259, 278 (1998) ("[P]roblems of unequal treatment of rural and urban patients can be dealt with using telemedicine as a conduit to deliver these services."); Ellen Almer, Online Therapy: An Arm's-Length Approach, N.Y. Times, Apr. 22, 2000, at A1 (noting that:

Some experts on mental health agree that online counseling, through e-mail, real-time e-mail exchange, and eventually video conferencing, is one of the most promising developments of the maturing Internet because it opens up new treatment options to people in remote areas, the disabled and those who feel too stigmatized to seek treatment for mental illnesses.).

Such advantages might be particularly beneficial to the estimated 38.5 million Americans without health insurance and the estimated 43 million Americans living in "medically underserved" areas. See Rosenblatt et al., supra note 54, at 38, 40.

97 See Nancy K. Plant, Prescription Drug Promotion on the Internet: Tool for the Inquisitive or Trap for the Unwary?, 42 St. Louis U. L.J. 89, 155-56 (1998) (stating that:

In light of the changes in the healthcare system ... patients must take more responsibility for their own healthcare. Physicians ... have their own set of conflicting interests to worry about .... In order for patients to manage their own healthcare responsibly, they must be able to obtain information and use it appropriately.);

Plant, supra note 50, at 1036 ("Patients are increasingly interested in and receptive to information about their diseases and possible modes of treatment."); William M. Silberg et al, Assessing, Controlling, and Assuring the Quality of Medical Information on the Internet: Caveat Lector et Viewor-Let the Reader and Viewer Beware, 277 JAMA. 1244, 1244 (1997) ("[T] he Internet hosts a large number of high-quality medical resources and poses seemingly endless opportunities to inform, teach, and connect professionals and patients alike."); Tyler, supra note 96, at 269 ("The necessity for information for one's diagnosis or medical options has never been more obvious than now when consumers are faced with government and medicare funding cutbacks, hospital closings, waiting lists for surgical procedures, and doctors' and nurses' strikes."); David J. Morrow, Health Care Consumers Can Expect Change, and a Shock or Two, N.Y. Times, Dec. 20, 1999, at C6 ("One of the biggest changes during the next 10 to 20 years is expected to be the increasing role of the patient in choosing his or her treatment. Instead of relying only on their doctors' advice, consumers will also use medical information from the Internet and prescription-drug ad campaigns."). 
cians, insurers, pharmacies, and manufacturers now conducted on reams of paper forms..$^{98}$

The AMA also has identified at least three situations in which Internet prescribing may be used for legitimate electronic prescribing purposes.99 For instance, after a physician examines a patient, she could enter a prescription order online for that patient and transmit it online to the pharmacy. ${ }^{100}$ Alternately, if a patient has been and remains under the care of a physician, and has been seen in person by the physician in the recent past, the patient could contact electronically the physician when no refills remain on a previous prescription, and the physician could authorize the renewal online to the pharmacy. ${ }^{101}$ Finally, the AMA notes that it may be appropriate for a physician to consult a patient online and issue that patient a new prescription pursuant to that online consultation if the physician has an ongoing relationship with the patient, has the patient's medical history and physical information available at the time of the consultation, and has seen the patient in the recent past. In this limited situation, new prescriptions for particular medications legitimately may be transmitted online to the pharmacy without an additional office visit. ${ }^{102}$ In light of these potential advantages, the AMA has stated that "[c]are must be taken to protect and even enhance legitimate electronic prescribing and dispensing practices."103 Therefore, it is important that prescribing-based sites are not abandoned merely be-

98 See Tyler, supra note 96, at 289 ("The benefits of on-line teleconferencing and consultations as well as the on-line practice of medicine in this era of limited bealth care dollars and managed care are inestimable."). Healtheon/NebMD, an Internet-based company, has already announced plans to link patients, doctors, and insurers online. See Milt Freudenheim, Confronting the Reality of a Health Care Vision, N.Y. Times, Feb. 28, 2000 , at $\mathrm{Cl}$ ("The potential market is a mindboggling 30 billion bealth care transactions annually."); see also Alissa R. Spielberg, On Call and Online: Sociohistorical, Legal, and Ethical Implications of E-Mail for the Patient-Physician Relationship, 280 JAMA 1353, 1353 (1998) (" $[\mathrm{E}]$-mail has the potential to reach every physician and in turn to alter all of a physician's subsequent relationships.").

99 See Drugstores on the Net, supra note 26, at 255 (statement of Herman I. Abromowitz); Report of the AMA, supra note 22, at 8.

100 See Drugstores on the Net, supra note 26, at 255 (statement of Herman I. Abromowitz).

101 See id.

102 See id. (using example of prescribing antihistamine pursuant to electronic consultation).

103 Id. Unfortunately, legitimizing prescribing-based sites may cnable some bad actors to obtain drugs fraudulently. Yet even under our current drug distribution system, bad actors can lie to their doctors and forge preseriptions to procure medication improperly. This Note does not consider whether such fraud will be pervasive enough to outweigh the benefits of online prescribing. Using a strict failure-to-wam liability analysis to limit the types of drugs available online, see infra Part III, hovrever, should prevent the most problematic drugs from being marketed in this way. 
cause of the inability of our current regulatory system to police the safety of these transactions. ${ }^{104}$

Only by improving prescribing-based sites and forcing them to operate responsibly, either by expanding the involvement of a doctor with the online transaction or by increasing the quality of the patient information provided, can their vast potential be realized. ${ }^{105}$ Unfortunately, it is doubtful whether legislative or administrative mandates effectively could compel these websites, notorious for their ability to evade regulation, to reform their prescribing methods. ${ }^{106}$ Furthermore, given the rapid pace of change within the Internet, such regulations likely will be obsolete before they are promulgated.107 Finally, any proposed solution must ensure that both domestic and foreign websites will act to increase the safety of their transactions.

III

Enhancing the Safety of Onzine Prescribing:

A Proposal

This Note proposes that pharmaceutical manufacturers themselves are optimally situated to improve the operation of prescribingbased sites. First, manufacturers can utilize the capabilities of the Internet to create comprehensive patient information systems that convey adequate warnings directly to the online patient. Scrutinizing patient information systems under a traditional failure-to-warn liability framework would increase effectively the quality of patient care provided by websites without imposing an absolute ban on online prescribing. Second, to ensure that warnings will be distributed by websites regardless of where in the world they are based, the manufacturers, and not the government, must obligate websites to implement these systems. By balancing manufacturers' commercial in-

104 See Cohen, supra note 27, at 1 ("'The regulatory system for drugs was created at a time when the Internet was not envisioned.' (quoting William Hubbard, deputy associate commissioner of FDA)). See generally Bendavid, supra note 25 (arguing that current regulatory scheme is largely outdated).

105 See Spielberg, supra note 98, at 1358 ("[E]lectronic communication, as a novel technology, is neither inherently unethical nor readily acceptable for medical practice. Rather, the emergence of electronic communication launches a reexamination of the necessary values for good communication in the patient-physician relationship."); Terry, supra note 18, at 350 (describing various "new manifestations of cybermedicine"); Tyler, supra note 96, at 283 ("Telemedicine could result in revolutionary changes in our bealth care delivery system."); Morrow, supra note 97 ("Health experts are confident that drugs will routinely be bought through the Internet, including treatments for serious conditions.").

106 See supra notes 22-37 and accompanying text.

107 See Green, supra note 26, at 368 (arguing that regulating Internet is "unlikely to be successful given that rapid technological advances can render such regulations obsolete by the time they are published"). 
terests in online prescribing, the practical advantages to consumers of online prescribing, and the health and safety concerns of patients, this proposal provides manufacturers with an economically viable way to enhance the safety of online prescribing.

\section{A. Conveying Adequate Warnings Directly to the Patient: Revisited}

The Internet can be used to create comprehensive patient information systems that improve the quality of the warnings conveyed to the online patient. Analyzing comprehensive patient information systems under traditional failure-to-warn liability, and indeed, even under the learned intermediary rule, will encourage safer forms of Internet prescribing. This Section suggests two approaches to satisfying manufacturers' duty to warn: enhancing the online physician-patient relationship or distributing Individualized Patient Reports (IPRs).

\section{Enhancing the Online Physician-Patient Relationship: Extending the Learned Intermediary Rule}

Increasing the amount of physician interaction given to the patient on each transaction is one way of enhancing the quality of patient information provided in the Internet prescribing context. Instead of merely presenting a prospective patient with an online questionnaire, for example, a website could implement an instant messaging system to allow the patient and a physician to interact with each other in real time. ${ }^{108}$ Such an information exchange, albeit virtual, would resemble more closely a face-to-face examination in a physician's office than the typical online questionnaire. The physician would be able to ask all of her questions in real time and immediately receive the patient's answers, much as if they were speaking by telephone. If a court is convinced that the online information exchange is comprehensive enough to constitute a true physician-patient relationship and that the drug is dispensed according to an individualized medical judgment, then it should apply the learned intermediary

108 Instant messaging allows users to converse online at the pace of a normal conversation. For an example of instant messaging, see ICQ (visited July 8, 2000) chttp:/l www.icq.com>. This type of physician-patient communication already is being implemented by CyberDocs, (visited July 8, 2000) <http//inurv.cyberdoes.coms, which offers physician consultations through audio-video conferencing and/or interactive keyboard chat. There are also websites offering psychiatric counseling and treatment online. See here2listen.com (visited July 8, 2000) <http://www.here2listen.coms; mentalhealthline.com (visited July 18, 2000) <http://wwwmentalhealthline.com>; see also Jonathan Miandell, It's Often Fard to Find Help Behind the Cybercounter, N.Y. Times, Dec. 2, 1999, at G7 (discussing provision of customer service via interactive chat). 
rule. ${ }^{109}$ By extending the learned intermediary doctrine to cover such situations, courts would provide manufacturers with an incentive to develop these higher quality online information exchanges. Expanding the learned intermediary rule to protect websites that implement enhanced online physician-patient relationships will encourage the development of Internet prescribing into a reliable source for prescription drug consumers.

While a virtual examination may not be the ideal traditional consultation originally envisioned by the learned intermediary rule, our modern health care system has eviscerated the traditional physicianpatient relationship. ${ }^{110}$ Despite this, courts have continued to apply the learned intermediary rule, even in situations where the plaintiff argues that the physician-patient relationship was subpar.111 In Swayze v. McNeil Laboratories, Inc. ${ }^{112}$ the plaintiff's son died from an overdose of prescription anesthetic administered by a nurse anesthetist. 113 Though the nurse "testified that he alone determined the dosage,"114 the court found that since the physician "was present at all times ... he assumed the role of 'learned intermediary." "11s Similarly, in Bacardi v. Holzman, 116 the court applied the learned intermediary rule notwithstanding the plaintiff's claim that "he did not even know

109 If the current state of technology does not allow online information exchanges between physician and patient to rise to the level of a face-to-face consultation, courts should assign the duty to warn patients to the manufacturers. The manufacturers either will halt online sales or attempt to develop better ways to warn patients about their medications. For a thorough explanation of how a drug manufacturer should weigh liability risks, sec Swayze v. McNeil Lab., Inc., 807 F.2d 464, $477-79$ (5th Cir. 1987) (Goldberg, J., dissenting). The learned intermediary rule "carrot," however, will remain, encouraging manufacturers who wish to sell their medications online to develop the technology that will someday enable online information exchanges to become and be deemed true physician-patient relationships.

110 See supra Part II.B.

111 See, e.g., Pumphrey v. C.R. Bard, Inc., 906 F. Supp. 334, 339 (N.D. W. Va. 1995) (plaintiff argued that hospital setting did not allow for adequate communication between herself and surgeon); Krasnopolsky v. Warner-Lambert Co., 799 F. Supp. 1342, 1342 (E.D.N.Y. 1992) (plaintiff argued that doctor had examined him in impersonal clinical setting); Bacardi v. Holzman, 442 A.2d 617, 619 (N.J. Super. Ct. App. Div. 1981) (plaintiff argued that none of many different doctors he had seen at various clinics and hospitals individually had balanced risks involved); Taurino v. Ellen, 579 A.2d 925, 926 (Pa. Super. C. 1990) (plaintiff claimed that oral contraceptive was dispensed by clinic without intervention of physician).

112807 F.2d 464 (5th Cir. 1987).

113 See id. at 465 .

114 Id. at 466.

115 Id. at 470. In a noteworthy dissent, Judge Goldberg argued that "[t]he failure of a doctor to exercise his fiduciary duty to supervise care and to prevent unqualified persons ... from prescribing fentanyl cannot be consistent with performing a 'learned intermediary' role." Id. at 473 (Goldberg, J., dissenting).

116442 A.2d 617 (N.J. Super. Ct. App. Div. 1981). 
the names of some of the physicians who had treated him."117 The plaintiff in Taurino v. Ellen"118 argued that she was "supplied the drug by an employee of the clinic who was not a doctor."119 The court stated that "[e]ven assuming that [the plaintiff] was originally given Loestrin without the intervention of a physician[,] ... a physician did note that [the plaintiff] would take Loestrin before she began taking it," 120 and applied the learned intermediary rule. ${ }^{121}$

For many of the reasons discussed in Part II.A, courts are loath to disregard the learned intermediary rule even in situations where the quality of the physician-patient relationship is tenuous at best. 122 The continued availability of medication on the Internet, if within vigilantly controlled confines, should be afforded no less protection. Applying the learned intermediary rule to an online physician-patient relationship merely forces courts and manufacturers alike to examine carefully every aspect of the online relationship to ensure that it is similar in quality to a face-to-face consultation.123 For guidance on how to apply this standard, courts should look to the AMA's minimum standards of care..$^{224}$ If the court is satisfied that the online physician-patient relationship established by the prescribing-based site meets these criteria, it should extend failure-to-warn immunity to the manufacturer as long as it properly warned the online prescribing doctor. To conduct that analysis, a court should consider whether the doctor performed a thorough examination to determine whether an actual medical problem existed and to make a specific diagnosis. Second, there must be a dialogue between the physician and the patient to discuss treatment alternatives and to determine the best course of treatment. Third, the physician must effectively establish, or have ready access to, a reliable medical history. Fourth, the physician must

117 Id. at 619.

118579 A.2d 925 (Pa. Super. Ct. 1990).

119 Id. at 926 .

120 Id. at 928.

121 See id. at 930.

122 See Plant, supra note 50, at 1054 (" $[$ T] he doctrine better accommodates the prescription drug context than the application of traditional products liability failure-10-wam principles. Physicians may no longer have primary control over prescribing drugs, and consumers may have a greater need for more information about drugs; however, prescription drugs are still not a typical consumer product.").

123 Cf. Paytash, supra note 51, at 1364 ("It does not follow that because a more personalized doctor/patient relationship is preferable and ideal, that the lack of such a relationship renders medical decisions inadequate.").

124 See Drugstores on the Net, supra note 26, at 254 (statement of Herman I. Abromowitz) (outlining American Medical Association's minimum standards of care); Report of the AMA, supra note 22, at 5 ("[I]t is important to stress that the use of the Intermet does not obviate the physician's obligation to meet appropriate standards of care when dealing with patients."). 
provide adequate warning information to the patient. Finally, in certain cases, follow-up care will be necessary and the site will have to implement systems to make that possible.125

The promise of a safe harbor from failure-to-warn liability will encourage a manufacturer to screen carefully the websites it sells its products to and to work with those websites to develop enhanced online physician-patient relationships. Certainly, there will be drugs that are so complex that no amount of online information exchange will adequately inform the patient of the risks involved. ${ }^{126}$ In such cases, it will be unreasonable for the manufacturer to have relied on an online physician to provide sufficient information for the specific drug; it simply should not be dispensed online. However, there are many other medications that could be prescribed and dispensed safely online. By balancing patient safety concerns with the advantages of Internet prescribing, and then instituting proper safeguards, a certain number of prescribing-based sites will be improved markedly, allowing the public to benefit from a new, safe model of drug distribution.

\section{Leaving the Learned Intermediary Behind: A More Radical Proposal}

As an alternative to bolstering the online physician-patient relationship, manufacturers might help the websites to distribute enhanced patient warnings that improve upon the traditional PPI. Such a model assumes that a physician would issue the prescription pursuant to an online questionnaire much as they do now, with minimal patient interaction; therefore, the shield of the learned intermediary rule would be inappropriate. The website, however, could provide the patient with Individualized Patient Reports (IPRs) to compensate for the reduced role of the prescribing physician. Since these IPRs will be examined closely under a traditional failure-to-warn liability framework, manufacturers will have strong incentives both to design optimal warnings and to consider carefully which types of medications to allow to be distributed in this way.

125 See Drugstores on the Net, supra note 26, at 254 (statement of Herman I. Abromowitz).

126 Determining which medications could be appropriate for online prescribing would involve extensive therapeutic expertise; these reasonableness determinations probably will rely primarily on expert medical testimony. For a list of medications that one website has indicated as "inappropriate for online prescribing," see CyberDocs (visited July 8, 2000) <http://www.cyberdocs.com/nonprescribed.htm>. The list is primarily composed of controlled substances and is therefore not as well thought out as a court would require. It is presented merely as an oversimplified example. 
a. Individualized Patient Reports. (1) Comprehensive Patient Information Reports: Under this proposal, manufacturers, in conjunction with the FDA, should first fashion comprehensive patient information reports for all of the medications to be sold on prescribingbased sites. This process could mimic the one already in place for the approval of the contents of a new drug's professional labeling, which requires manufacturers to submit to the FDA "a great deal of information about how the drug should be used, and safety-related information that includes contraindications, known adverse effects, and precautions in usage to avoid identified risks."127 For most approved prescription medications, this information is already found on the drug's package insert. The bulk of the work would be translating this wealth of complex medical information into language readily comprehendible by lay persons.

(2) The Online Questionnaire: Once the report is created, the manufacturers should implement a standard online questionnaire to be used by the prescribing-based sites. Any individual characteristics that physicians would find pertinent in making their prescribing decisions, such as sex, race, age, weight, allergies, and blood pressure should be included in the questionnaire. In addition, manufacturers should include other more esoteric characteristics that are material in light of the particular drug being prescribed. The questionnaire must also contain a section where the patient can indicate any other medications she currently is taking. Creating the ideal questionnaire will be much like creating the ideal report, in that it will involve a careful balance between brevity and detail. It should not be overly lengthy, lest it tempt patients to skip parts of it, but it must be detailed enough to allow for as much individualized profiling as possible.

(3) Individualization: By using the patient's answers to the online questionnaire, the website could create an individualized profile of the patient.128 The IPR then could customize itself to conform to the answers provided in the questionnaire, emphasizing the information that a patient fitting that profile would find most material.129 For example, depending on whether the patient for which the drug was

127 Green, supra note 60, at 488; see also 21 CF.R. $\$ \S 601.2,601.12,601.25$ (2000); Viscusi et al, supra note 94, at 1440-46 (describing FDA's approval process for drug labeling).

128 For examples of profiling, see, e.g., My Yahoo! (visited July 8, 2000) <httpJ/ www.my.yahoo.com>; myCNN.com (visited July 8, 2000) <https/hnww.my.conn.com>.

129 See Henderson \& Twerski, supra note 79, at 307 (noting that "the order in which information is presented has a significant impact on its perception by the individual who must ultimately utilize the data to reach a decision"); Plant, supra note 50, at 1070 (arguing that manufacturers should be required to disclose information only when reasonable patient would find it material). 
intended was six years old or sixty years old, certain sections of the IPR would be highlighted, allowing the IPR to be comprehensive enough to encompass most known risks while minimizing "overwarning" the patient. The IPR could be shown to the patient online, preferably before the final order confirmation, so that the patient has a chance to review the pertinent risks of the medication before purchasing it. Once the medication is ordered, the IPR could be printed out and delivered with the patient's order. ${ }^{130}$

IPRs could effectively provide consumers who order drugs from prescribing-based sites with adequate warning information reasonably tailored to their individual profile, thus improving upon the traditional PPI. Of course, this printed information will in many cases be inferior to information received through personally consulting with a physician or by speaking directly to a dispensing pharmacist. Yet, measured against the quality of patient information typically provided in the current weakened state of the physician-patient relationship, this will not always be the case.

b. A Case for Traditional Failure-to-Warn Liability. If manufacturers choose to implement IPRs as described above, traditional failure-to-warn liability analysis would provide manufacturers with the proper incentives to police the Internet prescribing phenomenon, ensuring patient safety. In fact, it would be desirable if the exacting standards discussed in Part II.C.1.b prevented manufacturers from selling their medications to unscrupulous websites, distributing inadequate IPRs, or making particularly complex medications available to any website for online sale. Under this proposal, manufacturers will be free to partner with websites that they determine are reputable and create an extensive IPR program to accompany specific drugs they have deemed suitable for online sale. What the manufacturers must expect, however, is that the IPR thus created will be highly scrutinized under traditional failure-to-warn liability doctrine. The onus will be on the manufacturers to create the perfect IPR: readily understandable, sufficiently specific, and comprehensive. For certain medications this will be an impossible task, and liability concerns justifiably will prevent those medications from being sold online. Liability concerns will also deter manufacturers from selling their products to certain websites unable to implement an IPR program adequately. Likewise,

130 Additionally, the printout could include a toll-free phone number that patients could use to contact a health care professional with any additional questions they might have. Such a help center could be maintained by the manufacturer as part of their obligation to provide the PPIs and could serve as the final opportunity for the patients to receive highly individualized information about their medication. 
if these IPRs fail to improve upon traditional PPIs to any significant degree, this liability standard will restrict their use, thereby precluding manufacturers from relying on this method of disseminating warnings to patients to fulfill their duty to warn.

Admittedly, a proposal to rely on IPRs as the sole source of drug information undoubtedly will encounter tremendous resistance from the medical community. In the absence of an extensive physician-patient relationship, creating IPRs that are sufficiently specific, yet thorough enough to be the patient's primary information source, will be extremely difficult. At its most conservative, this proposal couldand probably should-be used as an adjunct to the enhanced onine physician-patient relationship described above. At its most extreme, such a proposal could force the reclassification of a particular class of medications to "quasi-prescription"; that is, medications that, based on their side-effect profiles, can be dispensed safely with a minimal amount of physician involvement and an adequate amount of patient information. ${ }^{131}$ The possible weighing of the advantages and disadvantages that would be associated with the creation of a class of "quasi-prescription" medications, on the basis of either increased access or decreased cost, can only be debated once a feasible system for their distribution has been enabled. Regardless of whether a new class of "quasi-prescription" drugs ever arises, to the extent that this proposal improves upon the quality of traditional PPIs, it undoubtedly can be implemented within our current scheme of drug distribution.

\section{B. Distributing Adequate Risk Information in Internet Prescribing Situations}

Pharmaceutical manufacturers are best situated to make certain that adequate risk information will be provided by websites that distribute drugs and thus contractually should obligate websites to implement the proposals discussed in Part III.A. As outlined in Part I, it is unlikely that the government will be able to require all these sites, many of which are based in foreign countries, to distribute adequate patient warnings. The only common party to all of the sites around the world is the manufacturer, the source of all the medication sold on these sites, whether they are based in Boston or Bali. Since manufacturers are held to be experts on how their products are distributed, 132

131 Possible candidates may include prescription antihistamines such as Claritin or Allegra. These medications have a low incidence of side effects and are available without a prescription in Canada. The side effect information required in an adequate paticnt warning may be too complex for traditional over-the-counter labeling, but might be conveyed adequately in the manner proposed here.

132 See supra notes $41-42$ and accompanying text. 
they are required to know which of the wholesalers or pharmacies they currently deal with are involved with prescribing-based sites. In fact, federal regulations already require pharmaceutical manufacturers to track the distribution of their products carefully. Manufacturers must keep lists of all authorized distributors for their products. ${ }^{133}$ Prescription drug wholesalers must maintain detailed records of the companies they deal with and "drug pedigrees" for medications they sell. ${ }^{134}$ Every drug manufacturer must have the capability to notify

133 See 21 U.S.C. \& 353(c)(1)(B) ("Each manufacturer of a drug . . shall maintain at its corporate offices a current list of the authorized distributors of record of such a drug."); see also Robert T. Angarola \& Judith E. Beach, The Prescription Drug Marketing Act: A Solution in Search of a Problem?, 51 Food \& Drug LJ. 21, 41 (1996) (discussing adoption of regulation by FDA).

The possibility exists that drugs still may find their way onto the open market outside of authorized distribution channels, especially in poorly regulated forejgn jurisdictions. A plaintiff injured in this situation who seeks to indemnify the manufacturer will have to show that the manufacturer's breach of its duty to warn was the proximate cause of her injury. See Restatement (Third) of Torts: Products Liability $\$ 15 \mathrm{cmt}$. e (1997) (noting that causal connection is required between defect and harm). When drugs are diverted criminally or fraudulently, this may be a difficult showing for the plaintiff to make since courts often find that criminal acts of third parties break the chain of causation. See, e.g., Port Auth. v. Arcadian Corp., 189 F.3d 305, 319 (3d Cir. 1999) (stating that "the terrorists' actions were superseding and intervening events breaking the chain of causation," thus undermining plaintiffs' negligence claim); Gaines-Tabb v. ICI Explosives, USA, Inc., 160 F.3d 613, 621 (10th Cir. 1998) (stating that

under comment $b$ [of Restatement (Second) of Torts $\S 448$ ], the criminal acts of a third party may be foreseeable if (1) the situation provides a temptation to which a 'recognizable percentage' of persons would yield, or (2) the temptation is created at a place where 'persons of a peculiarly vicious type are likely to be' and holding that criminal conduct of bombers was unforeseeable and broke chain of causation); Henry v. Merck \& Co., 877 F.2d 1489, 1495 (10th Cir. 1989) (stating that "intervening factors [can break] the causal nexus between the original actor's careless behavior and the resulting injury" and that "[w]hen the intervening act is intentionally tortious or criminal, it is more likely to be considered independent"); McCarthy v. Sturm, Ruger \& Co., 916 F. Supp. 366, 369 (S.D.N.Y. 1996) (stating that:

Plaintiffs' argue that because Olin [the ammunition manufacturer] could have foreseen criminal misuse of its product, it should not have manufactured the ammunition. Plaintiffs do not allege, however, that any special relationship existed between Olin and Ferguson [the murderer who used ammunition made by Olin] that would give Olin the authority and ability to control Ferguson's actions. In the absence of such a relationship, New York courts do not impose a duty to control the actions of third parties.).

134 See 21 U.S.C. $8353(e)(1)(A)$ (1994) (stating that wholesale distributors who are not authorized distributors of record must "provide to the person who receives the drug a statement ... identifying each prior sale, purchase, or trade of such a drug"); 21 C.F.R. $\$ 205.5(a)(3)$ (2000) (stating minimum required information for licensure as wholesale prescription drug distributor includes "addresses, telephone numbers, and the names of contact persons for all facilities used by the licensee for the storage, handling, and distribution of prescription drugs"). These statements are commonly termed "drug pedigrees." Seo Angarola \& Beach, supra note 133, at $41-43$ (explaining drug pedigrees); see also 21 C.F.R. $\$ 205.50$ (2000) (setting out requirements for drug sales by wholesale drug distributors). 
"each of its affected direct accounts" about possible drug recalls. ${ }^{135}$ Also, since the websites maintain direct contact with the patient, forcing them to distribute risk information through these contractual arrangements alleviates many of the logistical difficulties previously mentioned. ${ }^{136}$ Therefore, as a precondition to selling their medications to a pharmacy or wholesaler that engages in Internet prescribing, manufacturers contractually should obligate purchasers to implement effective patient information systems. ${ }^{137}$

\section{Contractual Assignment of a Pharmaceutical Manufacturer's Duty to Warn}

Once a manufacturer creates a comprehensive patient information system, it then must obligate the websites to implement it effectively. The leading case permitting a pharmaceutical manufacturer to assign its duty to warn contractually is Mazur v. Merck \& Co. ${ }^{133}$ In Mazur, the Philadelphia health department purchased Merck's MMR II vaccine for the city's immunization program. ${ }^{139}$ Merck sold the medication pursuant to a contractual provision obligating the United States Centers for Disease Control (CDC) to ensure that the vaccine would be administered (1) on the basis of an individualized medical judgment by a physician, or (2) with meaningful warnings, provided directly to the patient. ${ }^{140}$ Pursuant to the latter provision, the CDC created an "Important Information Statement" informing patients in lay language of the risks of the vaccine, and obligated the Philadelphia health department to distribute the statement to vaccinees, or their

13521 CF.R. \& 7.49 (2000); see also Michael B. McMains \& Catherine M. Morrison, The Impact of Technological Advancement on Pharmaceutical Company Liability, 30 Ind. L. Rev. 487, 489 (1997) (explaining recall requirements).

136 See supra notes $75-77$ and accompanying text.

137 As discussed in supra note 72 , the purchaser could be a distributor or the website itself. The manufacturer either could contract directly with the website or with the distributor who would, in tum, contractually obligate the vebsite to implement these systems. The manufacturer should be able to bind foreign-based sites through these private contracts as well. It is beyond the scope of this Note, however, to consider the possible jurisdictional issues of enforcing such contracts.

138964 F.2d 1348 (3d Cir. 1992). For another case holding that Merck contractually could obligate the Centers for Disease Control (CDC) to warn the ultimate user, see Walker v. Merck \& Co., 648 F. Supp. 931,935 (M.D. Ga. 1986), afrd, 831 F.2d 1069 (11th Cir. 1987); see also Reyes v. Wyeth Lab., 498 F.2d 1264, 1276 (5th Cir. 1974) (4T] the manufacturer is required to warn the ultimate consumer, or lo see that he is "'armed." (emphasis added)); Davis v. Wyeth Lab., Inc., 399 F.2d 121, 131 (9th Cir. 1968) ("Mt is the responsibility of the manufacturer to see that warnings reach the consumer, either by giving warning itself or by obligating the purchaser to give warning" ${ }^{n}$ ).

139 See Mazur, 964 F.2d at 1350.

140 See id at 1351. 
parents or guardians. 141 Applying the mass immunization exception to the learned intermediary rule, ${ }^{142}$ the court first held that Merck did indeed have an obligation to warn users directly of the risks of its vaccine. ${ }^{143}$ Applying the Restatement (Second) of Torts $\$ 388$, however, the court also held that "a vaccine manufacturer may satisfy its duty to warn in the mass immunization context by obligating the CDC to warn users directly if it informs that agency of the facts which make its vaccine dangerous and reasonably relies on it to communicate such information to users in lay terms." 144 The court first concluded that the package circular distributed with the MMR II vaccine was adequate to inform the $\mathrm{CDC}$ of the dangers associated with the vaccine. ${ }^{145}$ The court also noted that Merck had researched the CDC carefully before agreeing to sell its vaccine and continually monitored the CDC's dissemination efforts. ${ }^{146}$ Finally, "[g]iven the resources and funding available to the $\mathrm{CDC}$, as well as its expertise in immunology and public vaccination," the court held that Merck reasonably relied on the CDC to warn users of its vaccine directly. ${ }^{147}$

In order to ensure that prescribing-based sites will distribute adequate warnings, pharmaceutical manufacturers should draft contracts similar to Merck's contract with the CDC in Mazur. That is, manufacturers either could obligate the site to dispense their drug only after an individualized medical decision by an online physician, or require them to distribute meaningful patient warnings (i.e., IPRs), thus ade-

141 See id. This arrangement is analogous to the proposal outlined supra Part III.A.2.

142 See supra note 58.

143 See Mazur, 964 F.2d at 1369.

144 Id. at 1365 . Under Pennsylvania law, the court noted that an unavoidably unsafe product under comment $\mathrm{k}$ is not considered under $\S 402 \mathrm{~A}$ but under $\S 388$, which requires the manufacturers to meet a standard of reasonableness, and not one of strict liability. Sce id. at 1364-66.

145 See id. at 1367.

146 See id. at 1368.

147 Id. Admittedly, the heavily case-specific nature of the "reasonableness" test may lead courts to reach varying results. In Allison v. Merck \& Co., 878 P.2d 948 (Nev. 1994), the plaintiff was injured in a similar situation by the same MMR II vaccine. See id. at 95152. Even though Merck contractually had obligated the CDC to warn the vaccinees, the court found that the CDC had "admitted biases against 'discourag[ing] the use of vaccines." Id. at $958 \mathrm{n} .17$ (alteration in original). Accordingly, the court reasoned that " $\mathrm{a}$ jury could conclude that Merck knew or had reason to know that the CDC was not going to provide the truth about Merck's product and did not, in fact, give proper warning." Id. Therefore, "Merck fully realized how inadequate the warning really was." Id. In a dissenting opinion, Justice Young concluded that Merck reasonably relied on the CDC to formulate and distribute proper warnings for its vaccine. See id. at 968.69 (Young, J., dissenting).

However, the ambiguity inherent in any reasonableness test can also be its strength. Courts adjudicating Internet prescribing cases will confront ever evolving technology. A reasonableness test will be flexible enough to encompass the widely varying fact patterns that courts are sure to encounter. 
quately informing them of the pertinent dangers in the products. Mazur's reasonableness test would encourage manufacturers to investigate these sites carefully, examining the site's credibility, the procedures that it would use to implement a patient information program, and the resources that the site may or may not have in place to create a proper physician-patient relationship. It would not be reasonable for a manufacturer to enter into such contracts with every prescribingbased site, and the knowledge that dealing with an unscrupulous site may expose it to potential liability will discourage the manufacturer from dealing with such sites. A careful application of the Mazur test ensures that manufacturers maintain ultimate responsibility over the implementation of the warning system. ${ }^{148}$

The reasonableness test also would limit the types of medications sold online, encouraging manufacturers to consider carefully whether it is reasonable for particular drugs to be distributed online. ${ }^{149}$ Manufacturers would also have the duty to visit these sites often to monitor the effectiveness of their warning efforts and to refuse to sell their medications to any sites that are not complying with their contractual obligations.

Contractually obligating prescribing-based sites to distribute patient warnings is an efficient way to require these websites to improve their prescribing practices. By obligating certain prescribing-based sites to implement adequate patient safeguards, some of the sites will become viable alternatives to the traditional drug distribution system.

148 Courts that have addressed the delegation of the duty to varn by a pharmaccutical manufacturer emphasize that the manufacturer must maintain ultimate responsibility over the warning system it chooses to implement. See Petty v. United States, 740 F.2d 1428, 1440 (8th Cir. 1984) ("Delegation of the duty [to warm] does not, in itself, relieve the manufacturer ... from liability for deficiencies in the manner in which the chosen intermediary effectuates the manufacturer's duty."); Allison, 878 P.2d at 959 ("[A]lthough a manufacturer may decide to assign its duty to warn of the unsafeness of its product to others, a manufacturer cannot be relieved of ultimate responsibility for assuring that its unsafe product is dispensed with a proper warning."). In Petty, the U.S. government had assumed the duty to warn about a swine flu vaccine from the vaccine manufacturer. See Petty, 740 F.2d at 1439-41. The court held that the government's warning was inadequate and therefore the manufacturer was liable. See id at $1441 \& \mathrm{n} .12$

149 See Swayze v. McNeil Lab., Inc., 807 F.2d 464, 477 (5th Cir. 1987) (Goldberg, J., dissenting) ("If McNeil [drug manufacturer] had preferred not to run the foreseenble risk of liability, McNeil could have changed the circumstances under which it provided the drug.").

Though there are no large-scale studies available showing that telemedicine is as safe and effective as in-person consultations with a physician, a small study conducted by the Medical College of Georgia found no difference between the diagnoses physicians made using a telecommunications link and those diagnoses they made in person. See Tyler, supra note 96, at 279. For further discussion of telemedicine and possible medical malpractice liability, see generally Kearney, supra note 29, at 300-02; Spielberg, supra note 29, at 287-93. 
Those sites that refuse to, or cannot, adhere to these contractual guidelines will be cut off from their drug supply by the manufacturers and will wither away.

\section{Conclusion}

Internet prescribing has the potential to put millions of consumers at the risk of injury, presenting pharmaceutical manufacturers with a host of potential liability concerns. These concerns must be balanced against the tremendous commercial possibilities and practical advantages offered by Internet prescribing. At this early stage, with the full potential of the Internet far from realized, it would be inadvisable and unnecessary for the government to place wholesale restrictions on prescribing-based websites. Instead, failure-to-warn analysis can be used as a framework for drug manufacturers to improve the quality and safety of Internet prescribing. By encouraging the development of safer forms of Internet prescribing, instead of banning it entirely, the public can continue to benefit from the online health care revolution. 
